\title{
Working
}

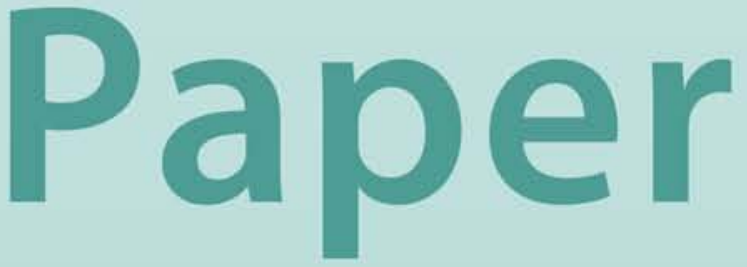




\section{Global Imbalances: \\ The Role of Non-Tradable Total Factor Productivity in Advanced Economies}

Pietro Cova, Massimiliano Pisani, Nicoletta Batini, and Alessandro Rebucci 


\title{
IMF Working Paper
}

\author{
Research Department
}

\section{Global Imbalances: The Role of Non-Tradable Total Factor Productivity in Advanced Economies ${ }^{1}$}

\section{Prepared by Pietro Cova, Massimiliano Pisani, Nicoletta Batini, Alessandro Rebucci}

Authorized for distribution by Jorg Decressin

March 2009

\begin{abstract}
This Working Paper should not be reported as representing the views of the IMF.

The views expressed in this Working Paper are those of the author(s) and do not necessarily represent those of the IMF or IMF policy. Working Papers describe research in progress by the author(s) and are published to elicit comments and to further debate.
\end{abstract}

This paper investigates the role played by total factor productivity (TFP) in the tradable and nontradable sectors of the United States, the euro area, and Japan in the emergence and evolution of today's global trade imbalances. Simulation results based on a dynamic general equilibrium model of the world economy, and using the EU KLEMS database, indicate that TFP developments in these economies can account for a significant fraction of the total deterioration in the U.S. trade balance since 1999, as well as account for some the surpluses in the euro area and Japan.

Differences in TFP developments across sectors can also partially explain the evolution of the real effective value of the U.S. dollar during this period.

JEL Classification Numbers: $\quad$ E0, F3, F4, G1

Keywords: global imbalances, productivity, trade deficit, exchange rates, non-tradable sector, GEM

Author’s E-Mail Address:pietro.cova@bancaditalia.it; massimiliano.pisani@bancaditalia.it; nbatini@imf.org; alessandroR@iadb.org

\footnotetext{
${ }^{1}$ A shorter version of this paper is published in the IMF Staff Papers. The authors thank Susanto Basu, Francesco Giavazzi, Luca Guerrieri, Ben Hunt, Ellen McGrattan, Enrique Mendoza, Gian Maria Milesi-Ferretti, Sergio Rebelo, and seminar and conference participants at the central bank of Chile, Italy, and Peru, the University of Surrey, the 2007 IMF Modeling Conference, and 11th CEPR/ESI Annual Conference on Global Imbalances for helpful discussions and suggestions.
} 


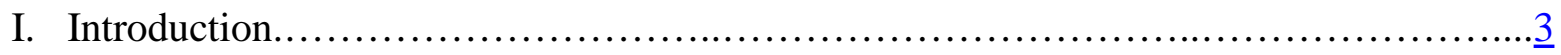

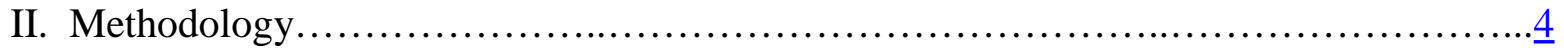

A. Mode, Calibration, and Solution.......................................

B. TFP Paths............................................................

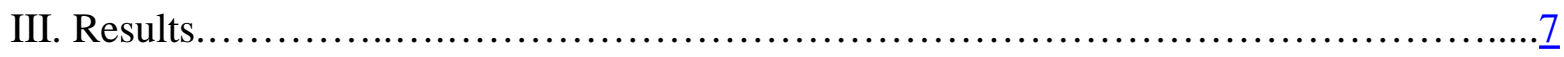

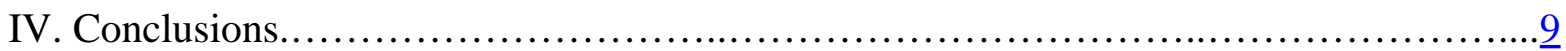

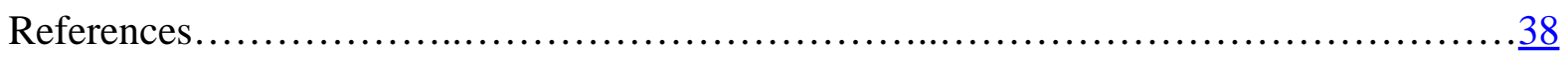

\section{Tables}

1. Annual Average Total Factor Productivity Growth by Sector and

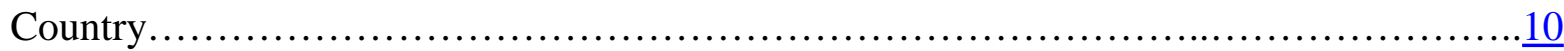

Figures

1. Global Merchandise Trade Balances...............................................11

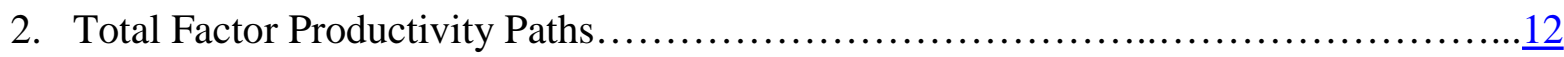

3. Actual and Simulated U.S. Trade Balance......................................

4. Actual versus Simulated Trade Balances .......................................14

5. Actual and Simulated U.S. Real Effective Exchange Rate............................15 


\section{INTRODUCTION}

During the 1990s, large trade imbalances developed in different regions of the world, with the United States running persistent deficits, and Japan and the euro area first, and later emerging Asia and oil-exporting countries, running surpluses (Figure 1). Today, the United States absorbs the majority of the world's current account surpluses, and net U.S. liabilities remain at record-high, representing over a fifth of U.S. GDP.

The debate about the sources and hence possible resolutions of these external imbalances is polarized. Some argue that global imbalances should not be resisted. This is because they largely manifest as an equilibrium phenomenon, generated by the interaction of growth and financial development differentials among countries, that will resolve themselves slowly over time---see, for example, Engel and Rogers (2006), Blanchard (2007), Caballero, Fahri, and Gourinchas (2007), Mendoza, Rull, and Quadrini (2007), Perri and Fogli (2007), and McGrattan and Prescott (2007). Many, however, trust that these imbalances originate in economic distortions, and they should be resolved primarily through policy adjustment, including significant changes in effective exchange rates and fiscal policies or both---for instance, IMF (2005 and 2006), Blanchard, Giavazzi and Sa (2007), Mussa (2004), Obstfeld and Rogoff (2007), Roubini and Setser (2004), and Yoshitomi (2006).

One issue that, by contrast, is relatively undisputed is that differences in relative productivity across world regions have likely played a non-negligible role in the emergence and evolution of the today's trade imbalances. This general perception is supported by empirical evidence. Glick and Rogoff (1995), for example, estimate that a one percent increase in country-specific productivity decreases the current account balance by 0.15 percent of GDP. Estimates by Bems, Dedola and Smets (2007), Edwards (2007), and Corsetti, Dedola, and Leduc (2007) detect even larger elasticities between shocks to productivity and imbalances. A few recent studies also examined the potential role of total factor productivity (TFP) differences across countries in explaining the global imbalances, based on multi-country dynamic general equilibrium models with calibrated TFP processes. Erceg, Guerrieri, and Gust (2002) and Hunt and Rebucci (2005), for instance, find that a permanent shock to the level of TFP in the U.S., combined with uncertainty or learning about its persistence, can explain at least in part the behaviour of the U.S. trade deficit in the late 1990s.

As Obstfeld and Rogoff (2007) note, however, productivity could only help to reduce the large U.S. trade deficit if it were concentrated either in the tradable sector of the United States (as foreign goods become less attractive to both U.S. and non-U.S. residents) or in the non-tradable sector in the euro area and Japan (as this boosts their wage and capital income and hence their demand for U.S. goods). ${ }^{2}$ Reasoning along these lines, they infer that much

\footnotetext{
${ }^{2}$ Guerrieri, Henderson, and Kim (2005) also point out that the transmission of a TFP shock in the tradable sector may differ significantly from that of a shock in the non-tradable sector of the U.S. economy, in terms of the responses of the exchange rate and the trade balance.
} 
of the widening of the U.S. trade deficit over the past 10 years or so must have originated from the boom in relative productivity in the U.S. non-tradable sector.

This paper investigates the role played by TFP in the tradable and non-tradable sectors of the United States, the euro area, and Japan in the emergence and evolution of today's global trade imbalances. Specifically, we feed sector-specific TFP data from 1995 to 2004 for these countries, from a new and homogenous data set, to a flexible-price version of the dynamic general equilibrium model (DGE) of the world economy developed by Cova and Pisani (2007) at the Bank of Italy.

This model is a five-region DGE. It comprises an emerging Asia and a rest-of-theworld block, in addition to the United States, the euro area, and Japan and shares many features with the IMF’s GEM (i.e., Laxton and Pesenti, 2003; Hunt and Rebucci, 2005; Batini, N'Diaye, Rebucci, 2005; Faruqee et al., 2007). The model does not treat oil-exporting exporting economies separately. It does not incorporate realistic financial frictions, possibly inducing precautionary demands for official reserves or constraining the supply of marketable financial assets, as well as other policy distortions, such as sustained sterilized foreign exchange intervention. ${ }^{3}$

Subject to the caveat that the analysis in this paper focuses only on one among several factors likely to drive the current constellation of global imbalances, we find that TFP developments in advanced economies, and especially in the non-tradable sector of the United States, can account for a significant fraction of the total deterioration in the U.S. trade balance after 1999, as well as for some of the surplus periods in the euro area and Japan. Sector-specific productivity differentials in the United States also do well at capturing the direction, persistence, and turning point of the U.S. dollar effective exchange rate since mid1990s, although the volatility of the simulated exchange rate path is much smaller, and the turning point earlier, than in the data.

The rest of the paper is organized as follows. Section II describes the methodology that we employ, including the model, its calibration and solution, and the data. Section III presents and discusses the results. Conclusions and implications follow in Section IV.

\section{METHODOLOGY}

We feed to our model historically realized TFP paths for the United States, the euro area, and Japan. We then compare actual and simulated paths for the trade balance, as well as the real effective exchange rate and the national accounts. This section briefly describes the model, its calibration and solution, and the data that we use in the analysis.

\footnotetext{
${ }^{3}$ See IMF (2006 and 2007) on the role of oil prices and exchange rate changes for global imbalances.
} 


\section{A. Model, Calibration, and Solution}

The analysis uses a flexible price version of the model of the world economy developed by Cova and Pisani (2007) at the Bank of Italy. ${ }^{4}$ This is a five-region and twosector (tradable and non-tradable) DGE model with incomplete international asset markets, home bias in consumption and investment, international price discrimination (due to the presence of a distribution sector), capital accumulation, and non-zero net foreign asset positions in steady state. The five regions are the United States, Japan, euro area, emerging Asia, and the rest of the world. The calibration of the model draws on previous GEM work at the IMF and on the international real business cycle and trade literature. The model is coded in DYNARE and is solved using the deterministic (perfect foresight) simulation command "simul”, with a simulation length of 500 periods or quarters. ${ }^{5}$

In the simulations, we assume the world economy is in steady state in 1994:Q4 and that, after 2004:Q4, historical TFP paths for the United States, the euro area, and Japan, revert to trend at the rate of 0.001 per quarter (i.e., with an autoregressive coefficient of 0.999). The TFP paths of Emerging Asia and the rest of the world are assumed to remain in steady state throughout the simulation period. Given that the spillover from other countries' TFP evolution to the United States are very small (see below), we start the simulations in 1995. Thus, the simulations attach no weight to the 1990-1995 productivity slowdown in Japan and the euro area.

\section{B. TFP Paths}

We construct the historical path for TFP in the United States (US), the euro area (EA, defined here as EU-15), and Japan (JA), for the tradable and non-tradable sector, from the new EU KLEMS database “Growth and Productivity Accounts” (see euklems.net).

We identify the tradable sector with "Manufacturing" and the non-tradable with the weighted average of "Wholesale and retail trade," "Electricity, gas and water supply," and "Transportation, storage, and communication," with weights given by the relative value added within the sector. We include only a subset of all the sectors available because these are the most accurately measured (Basu and Fernald, 2006). The results reported in the next section, however, are robust to using a narrower definition of the non-tradable sector or a broader definition of the tradable sector.

\footnotetext{
${ }^{4}$ Specific model features, and the details of its calibration, are reported and discussed in the appendix.

5 The "simul" instruction uses a Newton method to solve simultaneously all the equations for every period (see Juillard, 1996). Simulations with up to 6000 periods give similar results. In the published version of the paper, the model is solved assuming that agents forecast recursively the future path of TFP. As the main results of the paper are robust to this change, here we report the results based on standard perfect foresight simulations as described above.
} 
The data is in line with the conventional wisdom about the evolution of productivity growth in these areas---e.g., Jorgenson (2003, 2005), Jorgenson and Motohashi (2005), Gordon (2004), Oliner, Sichel, and Stiroh (2007). Table 1 reports 5-year averages of annual TFP growth, together with their average over the whole sample period available, and from 1981 to 2004 for ease of comparison across countries. U.S. tradable TFP growth accelerated temporarily in late 1990s, while non-tradable TFP growth lagged behind for most of the 1990s, accelerating sharply only in the last 5-year period. In Japan, tradable TFP growth was below average during the 1990s, falling sharply in the first half of the 2000s. The fall in TFP growth in the non-tradable sector lagged by about five years, but was deeper and more persistent than that experienced in the tradable sector. In the euro area, tradable and nontradable TFP growth slowed down markedly in the 1990s. In the first half of the 2000s, tradable productivity recovered partially, while non-tradable productivity continued to decline. $^{6}$

Interestingly, while the differences in TFP growth across sectors and countries are large and persistent over the past 15 years or so, longer term averages are remarkably similar. The TFP growth acceleration in the tradable sector of the United States, in particular, appears to be temporary, consistent with the estimates of Ireland and Schuh (2007) for the degree of persistence of investment-specific technological progress.

Detrended historical TFP paths are computed taking country and sector specific gross percent deviations from linear trends. The country and sector specific linear trends are calculated as time averages from 1980 up to the beginning of the shock periods. The beginning of the shock periods, in turn, is identified maximizing the model-based simulation's ability to fit the U.S. trade balance path. The identified beginning of the shock periods are: 1995 and 2000 for the U.S. tradable and non-tradable sector, respectively; and 1990 and 1995 for the euro area and Japan tradable and non-tradable sector, respectively. The resulting historical TFP paths, from 1995 to 2004, are plotted in Figure 2.

Our quantitative results are somewhat sensitive to the time windows chosen to compute the averages used in the construction of the linear trends. Note, however, that the choice of these time windows can be interpreted as an assumption about the expectations agents have at the beginning of the shock period on the evolution of future TFP. ${ }^{7}$

\footnotetext{
${ }^{6}$ We also looked at the TFP evolution in emerging Asia, with data from Jaumotte and Spatafora (2007). These data point to a possible deceleration of TFP growth in the region, consistent with the notion of a catch up and convergence with more advanced economies. This slowdown, however, is modest and it is thus unclear to what extent it may have had impact on this region's large trade surplus after the mid-1990s crisis.

${ }^{7}$ Erceg, Guerrieri, and Gust (2002) and Hunt and Rebucci (2005), for instance, calibrate a learning process about future TFP growth to the time evolution of actual medium-term growth forecasts for the United States and show this can help improve the model's ability to match the data, especially consumption and the exchange rate. Introducing "news shocks", along the line of Jaimovich and Rebelo (2007), is an alternative way to address the same issue.
} 


\section{RESULTS}

The results compare actual and simulated paths. We simulated the model under four different scenarios: (i) U.S. non-tradable TFP only, (ii) U.S. tradable TFP only, (iii) both U.S. tradable and non-tradable TFP, and (iv), finally, tradable and non-tradable TFP in all three economies. Figure 3 plots the U.S. trade balance of goods and services as a share of GDP, in deviation from the model steady state, normalized so that the steady state is equal to the data in 1994:Q4 in all four scenarios. Figure 4 compares actual and simulated paths for the trade balance of the United States, Japan, the euro area, as well as emerging Asia, in the fourth scenario (measured as in Figure 3). Figure 5 plots the U.S. real effective exchange rate in the fourth scenario (in deviation from the model steady state, normalized so that the steady state is equal to the data value in 1994:Q4).

The simulation with only U.S. non-tradable TFP tracks the U.S. trade balance evolution reasonably well (Figure 3) from 1999 onward. U.S. non-tradable TFP declines mildly between 1995 and 1999, with a sharper fall in 1999, and then increases strongly through 2004 (Figure 2). The associated trade balance dynamics results from the net effect of three different forces. ${ }^{8}$ First, there is a "composition" effect associated with the complementarity between tradables and nontradables and the strong substitutability among tradables. Driven by TFP changes, the relative price of non-tradable goods first rises and then falls (not reported). Correspondingly, U.S. demand of nontradables first decreases and then increases. Because of the complementarity between tradables and nontradables, U.S. consumption of tradable goods also decreases first and then increases. The U.S. terms of trade first deteriorates and then improves, and, with high substitutability, foreign demand of U.S. tradables (U.S. imports of foreign tradables) first increases and then decreases (first decrease and then increase). Therefore, these composition effect tend to push the U.S. trade balance into surplus initially, and then into deficit. Second, there is consumption smoothing. Households initially decrease and then increase consumption, but less than the labor and capital income changes associated with actual TFP changes. This second force tends to offset the composition effect, initially increasing and then reducing the trade balance deficit. Third, firms postpone investment, which is relatively intensive in tradables and less biased toward U.S. goods than the consumption basket, towards relatively more productive times. ${ }^{9}$ This third force pushes the trade balance in the same direction as the composition effect, initially into surplus and then into deficit. As a result, the trade balance deteriorates significantly only after 1999, as the desire to anticipate consumption is initially dominated by the composition effect and the firms' desire to postpone investment.

The simulation with only U.S. tradable TFP results in a persistent and counterfactual trade balance improvement in the United States between 1996 and 2000 (Figure 3). U.S. tradable TFP declines slightly in 1995 and then increases sharply until 2001, when it starts to

\footnotetext{
${ }^{8}$ More details on the transmission mechanism are discussed in the appendix.

${ }^{9}$ The share of tradable goods in aggregate investment and consumption is 0.75 and 0.35 , respectively. The bias towards domestic goods in the traded good basket of both the investment and consumption composite good is 0.87 .
} 
revert toward its trend (Figure 2). The transmission mechanism is similar to the one for nontradable TFP. Consumption and investment gradually rise over time as labor and capital income increase. However, the composition effect depresses the U.S. terms of trade sharply and persistently, in this case, after a short-lived improvement. ${ }^{10}$ World demand, therefore, shifts strongly in favor of U.S. tradable goods after 1996, driving the trade balance into persistent surplus. Not surprisingly, the simulation with both tradable and non-tradable U.S. TFP tracks the evolution of the U.S. trade balance less well than in the case of only nontradable TFP, with the deficit deteriorating persistently only after 2003 in the latter case.

The simulation with tradable and non-tradable TFP in all three economies tracks relatively well the trade balance of the euro area and Japan. In the case of emerging Asia, however, the model cannot account for the very large trade balance reversal associated with the crisis in 1997 and 1998 (Figure 4). ${ }^{11}$ For the euro area, the model fit is better in the first part of the simulation period, while for Japan the fit is better in the second part. ${ }^{12}$ Note, however, that the relatively large TFP swings that we feed to the model have small spillover effects to other countries. For instance, adding the TFP evolution of the euro area and Japan to the model (as in the fourth scenario reported) has essentially no impact on the U.S. trade balance evolution (Figure 3). This is in part because TFP changes in the euro area and Japan, during this period, are not conducive to large trade balance surpluses in these countries, but also because, in our multi-country model, the largest trade linkages of the United States are with the rest of the world, which in our calibration includes Canada and Mexico.

The simulation with tradable and non-tradable TFP in all three economies also tracks the evolution of the U.S. real effective exchange rate relatively well. The simulation tracks well the direction, persistence, and turning point of the exchange rate response, although the volatility is less, and the turning point is earlier, than in the data (Figure 5). For example, the dollar stops appreciating in 1998:Q4, when non-tradable productivity starts to increase, and starts to fall in 2000:Q4. However, in the data, the dollar reversal in 1999 is followed by a renewed sustained appreciation through end-2001. As for the transmission mechanism, the simulated exchange rate dynamics is driven by a Harrod-Balassa-Samuelson effect. The relative price of non-tradable goods first raises and then declines sharply, in the simulation, dominating movements in the terms of trade. This is both because of the timing differences in TFP changes across tradable and nontradable sectors, as well as the large share of the nontradable sector in the U.S. consumption basket.

These results are robust to the assumptions on the elasticity of substitution between home and foreign tradable goods, and between imports from different countries (see the working paper version of this article for more details on the latter). The results, however, are

\footnotetext{
${ }^{10}$ The relative price of non-tradable goods initially falls, but by less than the increase in the tradable good price (because of the complementarity between tradables and nontradables), and then increases over time.

${ }^{11}$ See Cova, Piasni and Rebucci (2009) for an analysis of emerging Asia role in the global imbalances.

${ }^{12}$ We do not report model-based results for the rest of the world because we do not have a data benchmark for this aggregate due the well known global trade discrepancy.
} 
sensitive to two other model features. First, reducing the value of the financial intermediation cost that determine model stationarity alters agents' intertemporal consumption smoothing possibilities, strengthening the consumption response, and hence resulting in larger trade deficits, at the beginning of the simulation period. ${ }^{13}$ Second, as we mentioned in the previous section, the results are also sensitive to the implicit assumptions on agent's expectations about future productivity, which would effectively alter actual TFP paths fed to the model.

Our results are partly consistent with the existing empirical literature. We find that a one percent increase in U.S. productivity in the non-tradable sector decreases the U.S. trade account by 0.16 percent of GDP (See Figure A2 in the appendix), a value at the lower end of the 0.15-0.5 range of elasticities in the empirical work of Glick and Rogoff (1995), Bems, Dedola and Smets (2007) and Edwards (2007). On the other hand, given our calibration of the model, the U.S. trade balance moves into surplus, and the U.S. terms of trade depreciate, in response to a one percent increase in tradable TFP (see Figure A1 in the appendix), which runs counter the recent empirical evidence of Corsetti, Dedola, and Leduc (2007).

\section{CONCLUSIONS}

This paper examined the role of TFP differences in the tradable and non-tradable sector of the United States, the euro area, and Japan on the emergence and evolution of today's constellation of global trade imbalances. Feeding these differences to a global, flexible price DGE model yields dynamics that are partially consistent with those observed in the data. The simulations can explain a significant fraction of the overall deterioration in the U.S. trade balance since 1999, some of the surpluses in Japan and the euro area, as well as the persistent U.S. exchange rate swings observed in the data. The basic mechanisms at work in the model, however, result in an exchange rate that is too little volatile compared to the data.

One important implication of the analysis is that, as past TFP accelerations seem persistent but ultimately temporary, and spillovers from TFP changes in individual countries appear small, rebalancing of the U.S., and hence global, trade imbalance should happen, at least in part, naturally, as the acceleration in U.S. non-tradable TFP slowly unwinds. More generally, the analysis highlights the importance of focusing on productivity developments in the non-tradable sector to understand the evolution of the trade balance and the exchange rate of large, relatively closed economies such as the United States, the euro area and Japan.

We see the analysis of TFP differences across sectors and countries in the presence of financial frictions and policy distortions as a natural complement of the work reported in this paper and a promising area of future research.

\footnotetext{
${ }^{13}$ In our simulations it would be possible to eliminate the adjustment costs on net foreign asset provided we specify the end value of the net foreign asset position, and solve the model with a two-point boundary algorithm (e.g., for instance, Mendoza and Tesar, 1998).
} 
Table 1. Annual Average Total Factor Productivity Growth by Sector and Country (Percent per year)

\begin{tabular}{|c|c|c|c|c|c|c|}
\hline & \multicolumn{2}{|c|}{ United States } & \multicolumn{2}{|r|}{ Japan } & \multicolumn{2}{|c|}{ EU-15 } \\
\hline & Tradables & Nontradables & Tradables & Nontradables & Tradables & Nontradables \\
\hline 1971-74 & 3.3 & 2.8 & na & na & na & na \\
\hline 1975-79 & 1.3 & 1.9 & 7.6 & 2.0 & na & na \\
\hline 1980-84 & 0.2 & -0.1 & 1.3 & 4.3 & 2.1 & 0.9 \\
\hline 1985-89 & 3.3 & 0.8 & 4.0 & 3.3 & 2.0 & 2.0 \\
\hline 1990-94 & 1.7 & 1.1 & -0.8 & 3.7 & 1.7 & 1.3 \\
\hline 1995-99 & 4.0 & 0.2 & 1.3 & 0.2 & 0.7 & 1.9 \\
\hline 2000-04 & 1.7 & 3.9 & 2.5 & 0.4 & 1.3 & 1.1 \\
\hline Average full sample & 2.2 & 1.5 & 2.8 & 2.4 & 1.5 & 1.5 \\
\hline Average 1981-04 & 2.4 & 1.3 & 1.8 & 1.7 & 1.5 & 1.5 \\
\hline
\end{tabular}

Source: EU KLEMS.

Note: Tradable sector identified with "Manufacturing”. Nontradable sector identified with the weighted average of "Wholesale and retail trade", "Electricity, gas and water supply”, and “Transportation, storage, and communication”, with weights given by the relative value added within the sector. 
Figure 1. Global Merchandise Trade Balances

(In percent of GDP)

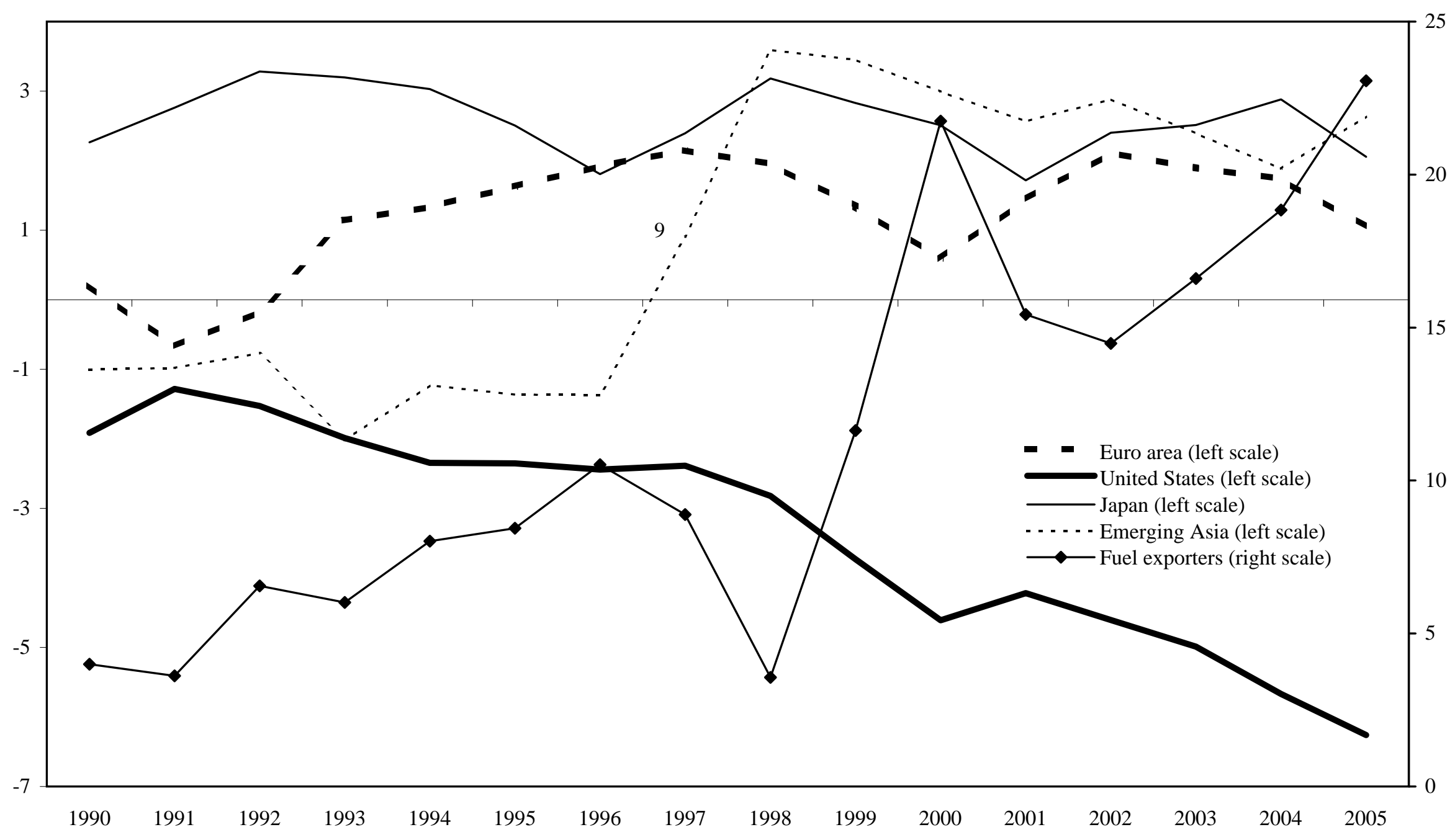




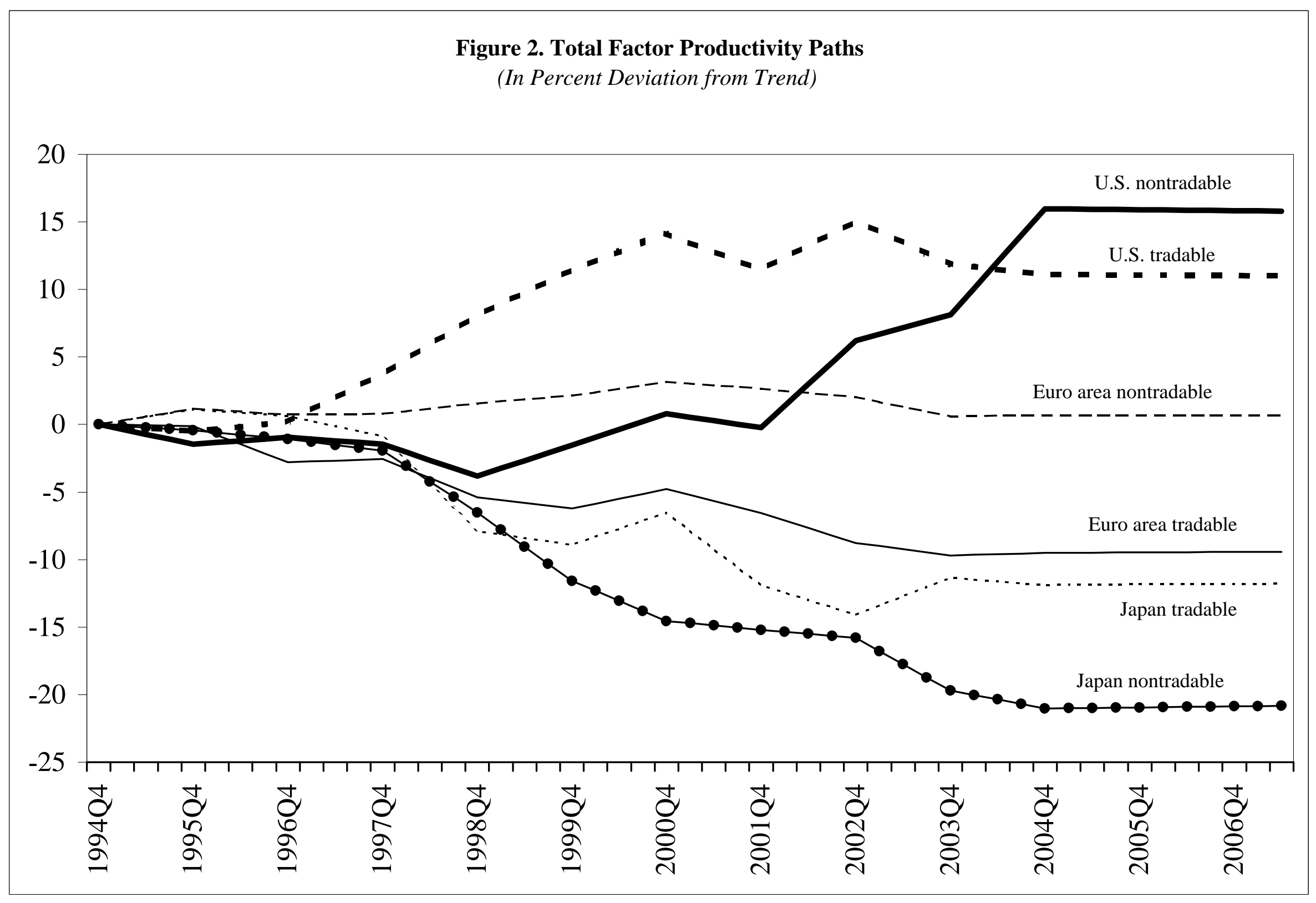




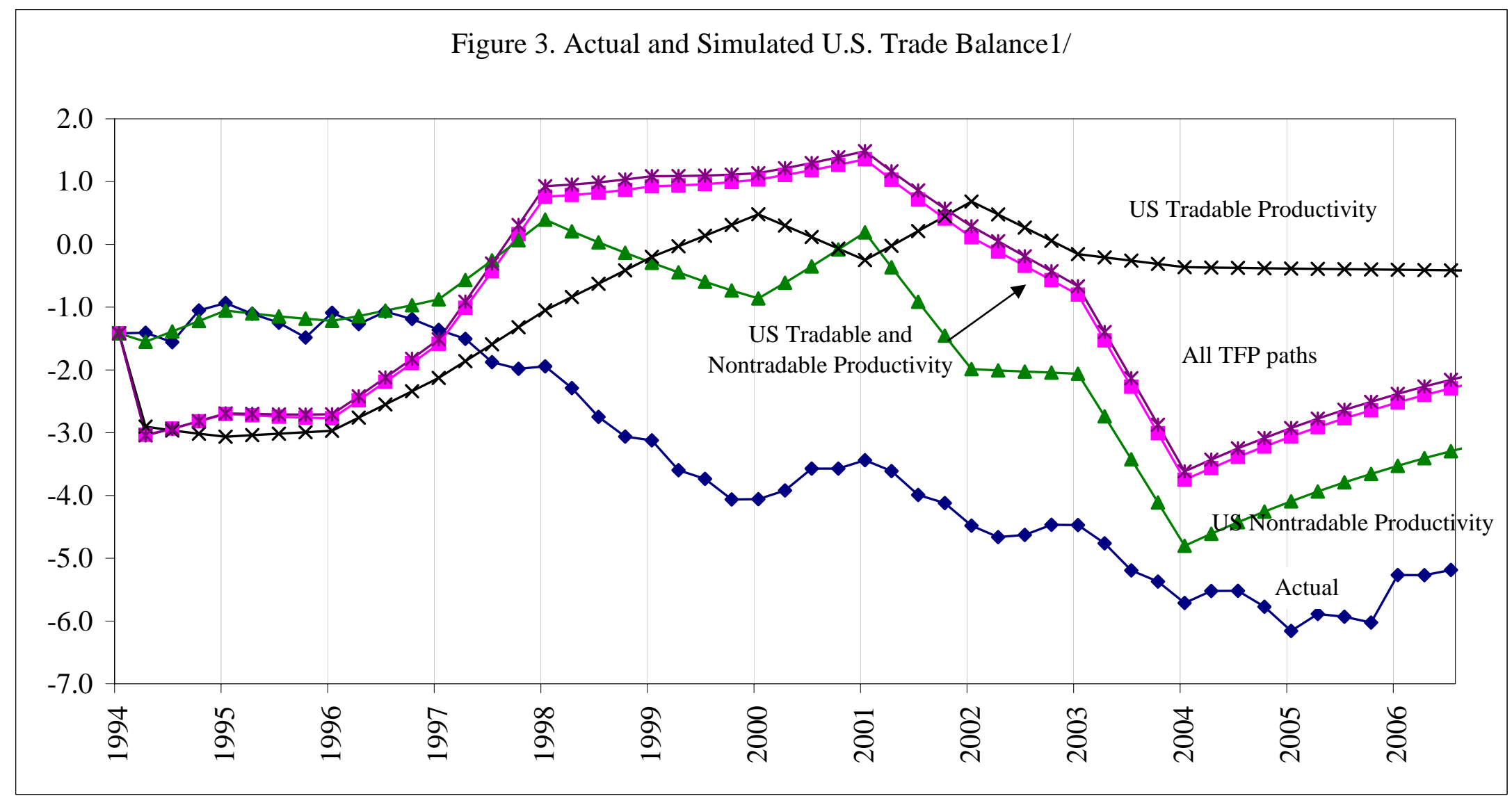

1/ Actual in percent of GDP; Simulated in percentage points of GDP deviation from steady state. 
Figure 4. Actual versus Simulated Trade Balances (Percentage points of GDP deviation from steady state)

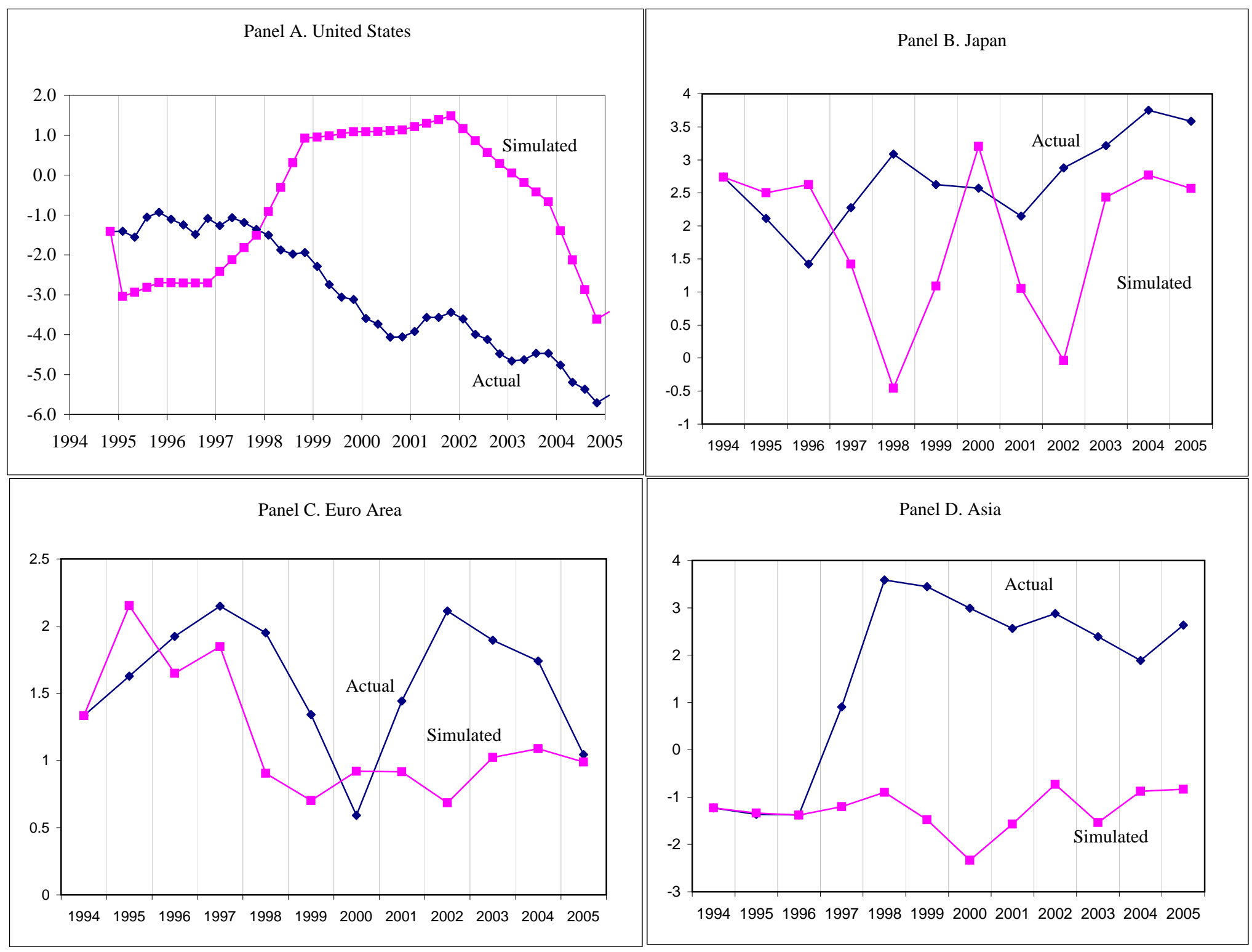




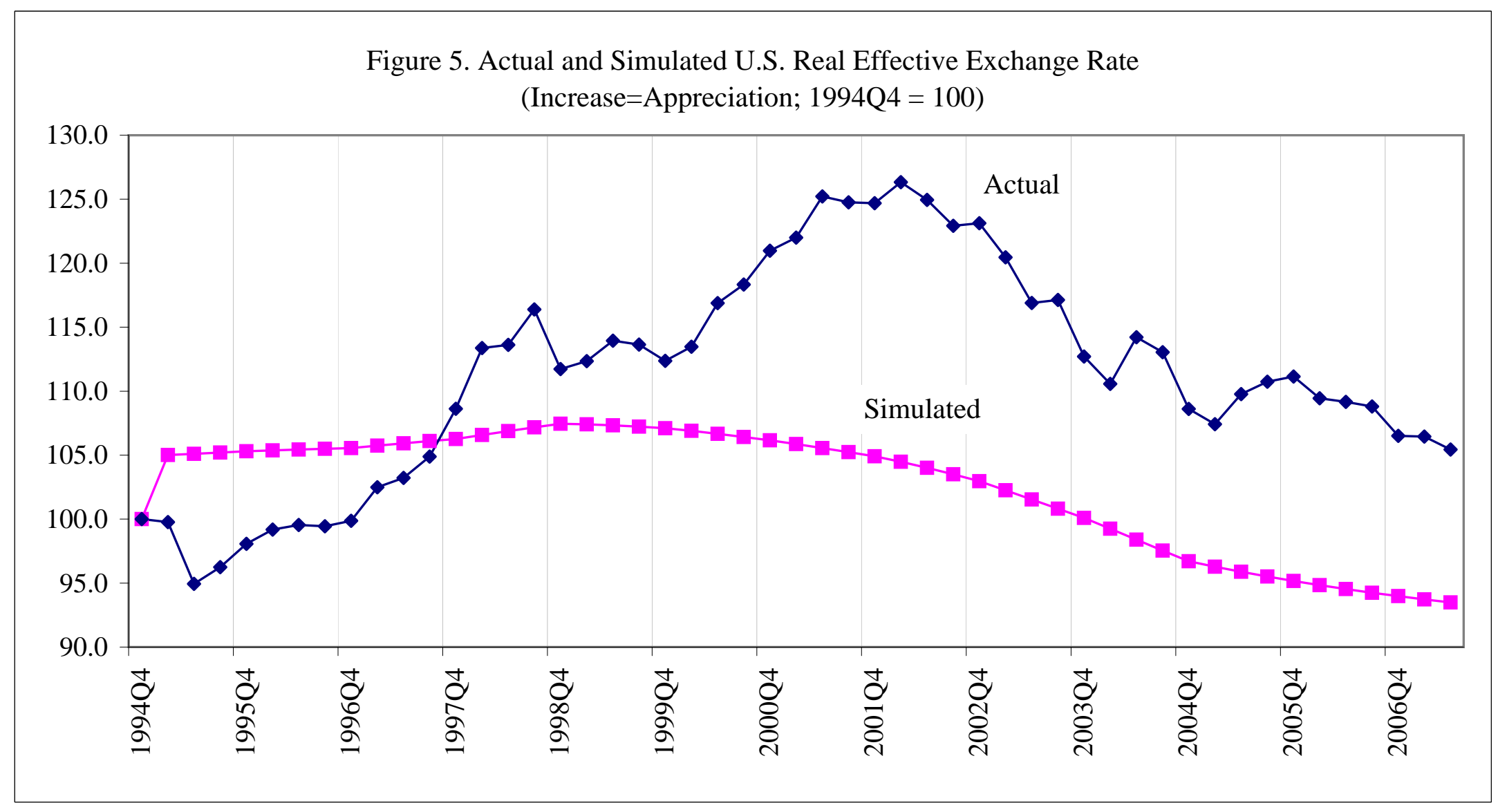




\section{THE MODEL}

In this appendix we describe the model, its calibration, and the solution technique that we use. The world economy consists of ve regional blocs ('countries'): United States (US), Japan (JAP), EA (Euro area), Emerging Asia (AS), and Rest of the World (ROW). In each country there are households, rms, and a government. World population is normalized to unity. Country sizes are denotes $s^{C O}$, with $\sum s^{C O}=1$. We denote $T R E N D_{t}$ the common stochastic trend for the world economy and $g_{t, \tau}$ its (gross) rate of growth, with $T R E N D_{\tau}=g_{t, \tau} T R E N D_{t}$. All quantity variables in the model are expressed in detrended terms, i.e. as ratios of $T R E N D$.

Each household is in nitely-lived, consumes a non-tradable nal good $(C)$, and is the monopolistic supplier of a differentiated labor input $(\ell)$ to all domestic rms. ${ }^{1}$

In each country there are two types of households: forward-looking or Ricardian ones (with subscript $F L$ ) and liquidity-constrained or non Ricardian ones (with subscript $L C$ ). Liquidityconstrained agents do not have access to capital markets and nance their consumption exclusively through income from labor. Forward-looking households own domestic rms and the domestic capital stock $(K)$, which they rent to domestic rms. The market for capital is competitive. Capital accumulation is subject to standard adjustment costs. Labor and capital are immobile internationally, but fully mobile across sectors.

Forward-looking households in each country also hold two short-term nominal bonds, one denominated in domestic currency and issued by the country's government, and another issued by the United States and denominated in US dollars and with a zero net supply worldwide. There are intermediation costs for national households entering the international bond market to induce stationarity. No other asset is traded internationally.

In each country, perfectly competitive rms produce two nal nontradable goods, a consumption good $(A)$ and an investment good $(E)$ using all types of intermediate goods as inputs (nontradables $N$, domestic tradables $Q$, and imports $M$ ). Intermediate goods come in different brands, each produced by a single rm under conditions of monopolistic competition with domestic labor inputs and domestic capital. Firms also provide intermediation services, without use of human or physical resources. All prices and wages are fully exible (the correspondent adjustment cost is set to zero). Therefore, there is no role for monetary policy in the model (in each country the interest rate rule imposes that the gross consumer price in ation rate equal to 1 in all period).

The government in each country consumes the two nal goods and nances its expenditures by issuing debt. The government's intertemporal solvency condition is guaranteed by a simple feedback rule according to which lump-sum taxes vary as the debt-to-GDP ratio deviates from some exogenous target ratio.

\footnotetext{
${ }^{1}$ Interpreting $T R E N D_{t}$ as labor-augmenting technical change, $\ell_{t}$ in the model is time devoted to work, assumed to be bounded by endowment, while effective labor is $T R E N D_{t} \ell_{t}$. It follows that the nominal wage (the monetary remuneration for one unit of labor services $\ell$ ) can be trending both because of nominal in ation and because of real (labor-augmenting) growth.
} 
As a general convention in the model, when we state that variable $X$ follows an autoregressive process, we mean that:

$$
X_{t}=X_{t-1}^{\rho_{X}} e_{X, t}
$$

where $0<\rho_{X}<1$ and $e_{X, t}$ is a noise term.

\section{A. Firms}

\section{Supply of intermediate goods}

In each country there are two kinds of intermediate goods, tradables and nontradables. Each kind is de ned over a continuum of brands of mass $s$. Without loss of generality, we assume that each nontradable brand is produced by a single domestic $\mathrm{rm}$ indexed by $n \in[0, s]$, and each tradable brand is produced by a $\operatorname{rm} h \in[0, s]$.

The nontradable brand $n$ is produced with the following CES technology:

$$
N_{t}(n)=Z_{N, t}\left[\left(1-\alpha_{N}\right)^{\frac{1}{\xi_{N}}} \ell_{t}(n)^{1-\frac{1}{\xi_{N}}}+\alpha_{N}^{\frac{1}{\xi_{N}}} K_{t}(n)^{1-\frac{1}{\xi_{N}}}\right]^{\frac{\xi_{N}}{\xi_{N}-1}}
$$

Firm $n$ uses labor $\ell(n)$ and capital $K(n)$ to produce $N(n)$ units of its brand. $\xi_{N}>0$ is the elasticity of input substitution, and $Z_{N}$ is a productivity shock common to all producers of nontradables.

De ning as $w_{t}$ and $r_{t}$ the relative prices of labor and capital (in units of domestic consumption), the marginal cost to produce nontradables is:

$$
m c_{t}(n)=\frac{\left\{\left(1-\alpha_{N}\right) w_{t}^{1-\xi_{N}}+\alpha_{N} r_{t}^{1-\xi_{N}}\right\}^{\frac{1}{1-\xi_{N}}}}{Z_{N, t}}
$$

and the capital-labor ratio is:

$$
\frac{K_{t}(n)}{\ell_{t}(n)}=\frac{\alpha_{N}}{1-\alpha_{N}}\left(\frac{r_{t}}{w_{t}}\right)^{-\xi_{N}}
$$

Labor inputs are differentiated by skills. They are de ned over a continuum of mass equal to the country size and indexed by $j \in[0, s]$. Each $\operatorname{rm} n$ uses a CES combination of labor inputs:

$$
\ell_{t}(n)=\left[\left(\frac{1}{s}\right)^{\frac{1}{\psi_{t}}} \int_{0}^{s} \ell(n, j)^{1-\frac{1}{\psi_{t}}} d j\right]^{\frac{\psi_{t}}{\psi_{t}-1}}
$$

where $\ell(n, j)$ is the demand of labor input of type $j$ by the producer of good $n$, and $\psi>1$ is the elasticity of substitution among different labor skills. Cost minimization implies that $\ell(n, j)$ is a 
function of the relative wage:

$$
\ell_{t}(n, j)=\left(\frac{1}{s}\right)\left(\frac{w_{t}(j)}{w_{t}}\right)^{-\psi_{t}} \ell_{t}(n)
$$

where $w(j)$ is the wage paid to Home labor input $j$ and the wage index $w$ is de ned as:

$$
w_{t}=\left[\left(\frac{1}{s}\right) \int_{0}^{s} w_{t}(j)^{1-\psi_{t}} d j\right]^{\frac{1}{1-\psi_{t}}}
$$

Similar considerations hold for the production of tradables. We denote by $T(h)$ the supply of each intermediate tradable $h$. Using self-explanatory notation, we have:

$$
T_{t}(h)=Z_{T, t}\left[\left(1-\alpha_{T}\right)^{\frac{1}{\xi_{T}}} \ell_{t}(h)^{1-\frac{1}{\xi_{T}}}+\alpha_{T}^{\frac{1}{\xi_{T}}} K_{t}(h)^{1-\frac{1}{\xi_{T}}}\right]^{\frac{\xi_{T}}{\xi_{T}-1}}
$$

where $Z_{T}$ is an autoregressive process (in logarithm). Aggregating across rms, we obtain the total demand for labor input $j$ as:

$$
\begin{aligned}
& \int_{0}^{s} \ell_{t}(n, j) d n+\int_{0}^{s} \ell_{t}(h, j) d h \\
& =\left(\frac{w_{t}(j)}{w_{t}}\right)^{-\psi_{t}}\left(\frac{1}{s}\right)\left(\int_{0}^{s} \ell_{t}(n) d n+\int_{0}^{s} \ell_{t}(h) d h\right) \equiv\left(\frac{w_{t}(j)}{w_{t}}\right)^{-\psi_{t}} \ell_{t}
\end{aligned}
$$

where $\ell$ is per-capita total labor in the economy.

\section{Price setting in the nontradable sector}

Consider now pro t maximization in the intermediate nontradable sector. Each $\mathrm{rm} n$ takes into account the demand (A-18) for its product and sets its price to maximize the real pro ts in each period.

The price-setting problem is then characterized as:

$$
\max _{p_{t}(n)}\left(p_{t}(n)-m c_{t}(n)\right)\left(\frac{p_{t}(n)}{p_{N, t}}\right)^{-\theta_{N}}\left(N_{A, t}+N_{E, t}+G_{N, t}\right)
$$

where $N_{A}, N_{E}$, and $G_{N}$ represent the nal demands by households and the government and $\theta_{N}>1$ is the elasticity of subsitution between nontradable brands. The optimization problem yields the standard constant mark-up pricing rule:

$$
p(n)=\frac{\theta_{N}}{\theta_{N}-1} m c_{t}(n)
$$

Since the rms $n$ are symmetric they all charge the same equilibrium price $p(n)=p_{N}$. 


\section{The distribution sector and price setting in the tradable sector}

As we want to focus on export markets, our notation needs to account explicitly for country indexes. In what follows we use the index $C O$ to denote a generic country, and denote $H$ the country where the exporting $\mathrm{rm} h^{H}$ is located.

Following Corsetti et al. (2004), we assume that tradeable-producing rms need distribution services intensive in local nontradeables to deliver their products to nal consumers. This implies that the elasticity of demand for any tradable brand is not necessarily the same across markets, re ecting asymmetries in the marginal costs and prices across the country-speci c distribution sectors. As a consequence, it is optimal to price discriminate across markets.

Firms in the distribution sector are perfectly competitive. They purchase home and foreign tradeable goods and distribute them domestically using a Leontief technology through which they combine one unit of the tradeable with $\eta \geq 0$ units of the basket of nontradeable brands $n$ :

$$
\eta \equiv\left[\int_{0}^{1} \eta(n)^{\frac{\theta_{N}-1}{\theta_{N}}} d n\right]^{\frac{\theta_{N}}{\theta_{N}-1}} \theta_{N}>1
$$

The distribution sector introduces a wedge $\eta$ between wholesale and consumer prices. Denoting with $\bar{p}_{\tau}^{C O}\left(h^{H}\right)$ and $p_{\tau}^{C O}\left(h^{H}\right)$ the wholesale and consumer prices of the home brand in country $C O$, and $\bar{p}_{\tau}^{H}\left(h^{H}\right)$ and $p_{\tau}^{H}\left(h^{H}\right)$ their domestic counterparts, respectively, consumer prices are given by:

$$
p_{t}^{H}(h)=\bar{p}_{t}^{H}(h)+\eta P_{N, t}^{H}, \quad p_{t}^{C O}(h)=\bar{p}_{t}^{C O}(h)+\eta P_{N, t}^{C O}
$$

where $P_{N}^{H}\left(P_{N}^{C O}\right)$ is the price of the home (generic importing country) composite basket $\eta{ }^{2}$

Consider now the price-setting problem in the tradables sector. As the distribution sector induces segmentation among ve national markets in the world economy, each $\mathrm{rm} h$ has to set ve prices, one in the domestic market and four in the export markets.

Taking equation (A-27) below into account, the four price-setting problems of $\mathrm{rm} h$ in country $H$ can then characterized as follows:

$$
\begin{aligned}
& \max _{\sum_{C O} \bar{p}_{t}^{C O}\left(h^{H}\right)} \sum_{C O} \\
& \left\{\left[\varepsilon_{t}^{H, C O} \bar{p}_{t}^{C O}\left(h^{H}\right)-m c_{t}^{H}\left(h^{H}\right)\right] * \frac{s^{C O}}{s^{H}}\left(\frac{p_{t}^{C O}\left(h^{H}\right)}{p_{M, t}^{C O, H}}\right)^{-\theta_{T}^{H}}\left(M_{A, t}^{C O, H}+M_{E, t}^{C O, H}+G_{H, t}^{C O, H}\right)\right\}
\end{aligned}
$$

${ }^{2}$ The price index $P_{N}^{C O}$ is:

$$
P_{N}^{C O}=\left[\int_{0}^{1} p^{C O}(n)^{1-\theta_{N}} d n\right]^{\frac{1}{\theta_{N}-1}}
$$

This is the minimum expenditure necessary to buy one unit of the basket $\eta$. 
When $H \neq C O$, recall that $\bar{p}^{C O}\left(h^{H}\right)$ is the wholesale price of good $h^{H}$ in country $C O, \bar{p}_{M}^{C O, H}$ is the wholesale price of country $C O$ 's imports from country $H$, and $M_{A}^{C O, H}+M_{E}^{C O, H}$ are country $C O$ 's imports from country $H$. The term $\varepsilon^{H, C O}$ is the bilateral real exchange rate between country $H$ and country $C O$ (an increase in $\varepsilon^{H, C O}$ represents a real depreciation of country $H$ 's currency against country $C O))^{3} \theta_{T}^{H}>1$ is the elasticity of substitution between tradable brands produced in country $H$.

For the domestic prices of tradables $\bar{p}^{H}\left(h^{H}\right)$ we use (A-14) with $C O=H$, adopting the notational conventions $\bar{p}_{M}^{H, H}=\bar{p}_{Q}^{H}, M_{A}^{H, H}=Q_{A}^{H}$ and $M_{E}^{H, H}=Q_{E}^{H}$ as described in (A-19) below.

\section{Demand for domestic intermediate goods}

As we just saw in the last section, intermediate inputs come in different brands and are produced under conditions of monopolistic competition. They are then bundled by a continuum of symmetric rms indexed by $x \in[0, s]$, where $0<s<1$ is the country size, into two baskets of intermediate goods (tradable and nontradable) under perfect competition. Consider now the composition of the baskets of intermediate goods.

Focusing rst on the basket $N_{A}$, this is a CES index of all domestic brands of nontradables. Denoting as $N_{A}(n, x)$ the demand by $\mathrm{rm} x$ of an intermediate good produced by $\mathrm{rm} n$, the basket $N_{A}(x)$ is:

$$
N_{A, t}(x)=\left[\left(\frac{1}{s}\right)^{\frac{1}{\theta_{N, t}}} \int_{0}^{s} N_{A, t}(n, x)^{1-\frac{1}{\theta_{N, t}}} d n\right]^{\frac{\theta_{N}}{\theta_{N}-1}}
$$

Firm $x$ takes as given the prices of the nontradable goods $p(n)$ and minimizes its costs subject to its production technology (A-15). Cost minimization implies:

$$
N_{A, t}(n, x)=\frac{1}{s}\left(\frac{p_{t}(n)}{p_{N, t}}\right)^{-\theta_{N}} N_{A, t}(x)
$$

where $p_{N}$ is the price of one unit of the non-tradable basket, or:

$$
p_{N, t}=\left[\left(\frac{1}{s}\right) \int_{0}^{s} p_{t}(n)^{1-\theta_{N}} d n\right]^{\frac{1}{1-\theta_{N}}}
$$

The basket $N_{E}$ is similarly characterized. Aggregating across rms, and accounting for public demand of nontradables - here assumed to have the same composition of private demand — we

\footnotetext{
${ }^{3}$ All exchange rates are quoted in real terms, that is, in relative consumption units. Of course, $\varepsilon^{H, C O}=1 / \varepsilon^{C O, H}$ and $\varepsilon^{H, H}=1$.
} 
obtain the total demand for good $n$ as: ${ }^{4}$

$$
\int_{0}^{s} N_{A, t}(n, x) d x+\int_{0}^{s} N_{E, t}(n, e) d e+G_{N, t}(n)=\left(\frac{p_{t}(n)}{p_{N, t}}\right)^{-\theta_{N}}\left(N_{A, t}+N_{E, t}+G_{N, t}\right)
$$

Following the same steps we can derive the domestic demand schedules for the intermediate goods $h$ :

$$
\int_{0}^{s} Q_{A, t}(h, x) d x+\int_{0}^{s} Q_{E, t}(h, e) d e+G_{A, t}(h)=\left(\frac{p_{t}(h)}{p_{Q, t}}\right)^{-\theta_{T}^{H}}\left(Q_{A, t}+Q_{E, t}+G_{A, t}\right) .
$$

\section{Demand for imports}

The derivation of the foreign demand schedule for good $h$ shares the same functional form as (A-18) and (A-19) above and can be written as a function of the relative price of good $h$ (with elasticity $\theta_{T, t}$ ) and total foreign demand for imports.

Let us focus rst on import demand in the consumption good sector. Since we deal with goods produced in different countries, the notation needs to rely on speci c country indexes. Thus, we refer again to a generic country as $C O$, to the importing country as $H$, and to the representative rm in the consumption sector as $x^{H} \in\left[0, s^{H}\right]$. Its imports $M_{A}^{H}\left(x^{H}\right)$ are a CES function of baskets of goods imported from the other countries, or:

$$
M_{A, t}^{H}\left(x^{H}\right)^{1-\frac{1}{\rho_{A}^{H}}}=\sum_{C O \neq H}\left(b_{A}^{H, C O}\right)^{\frac{1}{\rho_{A}^{H}}}\left(M_{A, t}^{H, C O}\left(x^{H}\right)\right)^{1-\frac{1}{\rho_{A}^{H}}}
$$

where:

$$
0 \leq b^{H, C O} \leq 1, \quad \sum_{C O \neq H} b^{H, C O}=1
$$

In (A-20) above, $M_{A}^{H, C O}\left(x^{H}\right)$ denotes imports of country $H$ 's $\mathrm{rm} x^{H}$ from country $C O$, while $\rho_{A}^{H}$ is the elasticity of import substitution across countries: the higher $\rho_{A}^{H}$, the easier it is for $\mathrm{rm}$ $x^{H}$ to substitute imports from one country with imports from another. The parameters $b_{A}^{H, C O}$ determine the composition of the import basket across countries.

Denoting $p_{M}^{H, C O}$ the relative price in country $H$ of a basket of intermediate inputs imported from $C O$, cost minimization implies:

$$
M_{A, t}^{H, C O}\left(x^{H}\right)=b_{A}^{H, C O}\left(\frac{p_{M, t}^{H . C O}}{p_{M A, t}^{H}\left(x^{H}\right)}\right)^{-\rho_{A}^{H}} M_{A, t}^{H}\left(x^{H}\right)
$$

\footnotetext{
${ }^{4}$ Variables which are not explicitly indexed (to rms or households) are expressed in per-capita (average) terms. For instance $A_{t} \equiv(1 / s) \int_{0}^{s} A_{t}(x) d x$.
} 
The import price in the consumption sector, $p_{M A}^{H}$, is de ned as:

$$
p_{M A, t}^{H}\left(x^{H}\right)=\left[\sum_{C O \neq H} b^{H, C O}\left(p_{M, t}^{H, C O}\right)^{1-\rho_{A}^{H}}\right]^{\frac{1}{1-\rho_{A}^{H}}}
$$

In principle, the cost-minimizing import price $p_{M A}^{H}\left(x^{H}\right)$ is rm-speci c, as it depends on $\mathrm{rm}$ $x^{H}$ 's import share. To the extent that all rms $x^{H}$ are symmetric within the consumption sector, however, there will be a unique import price $p_{M A}^{H}{ }^{5}$

Let us now consider the basket $M_{A}^{H, C O}\left(x^{H}\right)$ in some detail. In analogy with (A-15) above, it is a CES index of all brands of tradable intermediate goods produced by $\mathrm{rms} h^{C O}$ operating in country $C O$ and exported to country $H$. Denoting as $M_{A}^{H, C O}\left(h^{C O}, x^{H}\right)$ the demand by $\operatorname{rm} x^{H}$ of an intermediate good produced by $\operatorname{rm} h^{C O}$, the basket $M_{A}^{H, C O}\left(x^{H}\right)$ is:

$$
M_{A, t}^{H, C O}\left(x^{H}\right)=\left[\left(\frac{1}{s^{C O}}\right)^{\frac{1}{\theta_{T, t}^{C O}}} \int_{0}^{s^{C O}} M_{A, t}^{H, C O}\left(h^{C O}, x^{H}\right)^{1-\frac{1}{\theta_{T}^{C O}}} d h^{C O}\right]^{\frac{\theta_{T}^{C O}}{\theta_{T}^{C O}-1}}
$$

where $\theta_{T}^{C O}>1$ is the elasticity of substitution among intermediate brands, the same elasticity entering (A-19) in country $C O$.

The cost-minimizing $\mathrm{rm} x^{H}$ takes as given the prices of the imported goods $p^{H}\left(h^{C O}\right)$ and determines its demand of good $h^{C O}$ according to:

$$
M_{A, t}^{H, C O}\left(h^{C O}, x^{H}\right)=\frac{1}{s^{C O}}\left(\frac{p_{t}^{H}\left(h^{C O}\right)}{p_{M, t}^{H, C O}}\right)^{-\theta_{T}^{C O}} M_{A, t}^{H, C O}\left(x^{H}\right)
$$

where $M_{A, t}^{H, C O}\left(x^{H}\right)$ has been de ned in (A-22) and $p_{M}^{H, C O}$ is:

$$
p_{M, t}^{H, C O}=\left[\left(\frac{1}{s^{C O}}\right) \int_{0}^{s^{C O}} p_{t}^{H}\left(h^{C O}\right)^{1-\theta_{T}^{C O}} d h^{C O}\right]^{\frac{1}{1-\theta_{T}^{C O}}}
$$

The import demand schedules in the investment good sector can be derived in the same way. Finally, we can derive country $C O$ 's demand schedule for country $H$ 's intermediate good $h^{H}$, that is, the foreign equivalent of (A-19). Aggregating across rms (and paying attention to the order of the country indexes) we obtain:

$$
\begin{aligned}
& \int_{0}^{s^{C O}} M_{A, t}^{C O, H}\left(h^{H}, x^{C O}\right) d x^{C O}+\int_{0}^{s^{C O}} M_{E, t}^{C O, H}\left(h^{H}, e^{C O}\right) d e^{C O}+G_{A, t}^{C O, H}(h) \\
& =\frac{s^{C O}}{s^{H}}\left(\frac{p_{t}^{C O}\left(h^{H}\right)}{p_{M, t}^{C O, H}}\right)^{-\theta_{T, t}^{H}}\left(M_{A, t}^{C O, H}+M_{E, t}^{C O, H}\right)+\left(\frac{p_{t}^{C O}\left(h^{H}\right)}{p_{M, t}^{C O, H}}\right)^{-\theta_{T}^{H}} G_{A, t}^{C O, H}(h)
\end{aligned}
$$

${ }^{5}$ It follows that $p_{M A}^{H} M_{A}^{H}=\sum_{C O \neq H} p_{M}^{H, C O} M^{H, C O}$ 


\section{Final goods}

The baskets of intermediate goods are used in each country by a continuum of symmetric rms to produce two nal goods, the consumption good $(A)$ and the investment good $(E)$ under perfect competition. ${ }^{6}$

Consider rst the consumption sector. Each $\operatorname{rm}$ is indexed by $x \in[0, s]$, where $0<s<1$ is the country size. Indicating $\mathrm{rm} x$ 's output at time (quarter) $t$ with $A_{t}(x)$, the consumption good is produced with the following nested constant elasticity of substitution (CES) technology:

$$
\begin{aligned}
& A_{t}(x)^{1-\frac{1}{\varepsilon_{A}}}=\left(1-\gamma_{A, t}\right)^{\frac{1}{\varepsilon_{A}}} N_{A, t}(x)^{1-\frac{1}{\varepsilon_{A}}} \\
& +\gamma_{A, t}^{\frac{1}{\varepsilon_{A}}}\left[\nu_{A}^{\frac{1}{\mu_{A}}} Q_{A, t}(x)^{1-\frac{1}{\mu_{A}}}+\left(1-\nu_{A}\right)^{\frac{1}{\mu_{A}}} M_{A, t}(x)^{1-\frac{1}{\mu_{A}}}\right]^{\frac{\mu_{A}}{\mu_{A}-1}\left(1-\frac{1}{\varepsilon_{A}}\right)}
\end{aligned}
$$

Three intermediate inputs are used in the production of the consumption good $A$ : a basket $N_{A}$ of nontradable goods, a basket $Q_{A}$ of domestic tradable goods, and a basket $M_{A}$ of imported goods. The elasticity of substitution between tradables and nontradables is $\varepsilon_{A}>0$, and the elasticity of substitution between domestic and imported tradables is $\mu_{A}>0$. The weights of the three inputs are, respectively, $1-\gamma_{A}, \gamma_{A} \nu_{A}$ and $\gamma_{A}\left(1-\nu_{A}\right)$ with $0<\gamma_{A}, \nu_{A}<1$.

Firm $x$ takes as given the prices of the three inputs and minimizes its costs subject to the technological constraint (A-28). Cost minimization implies that $\mathrm{rm} x$ 's demands for intermediate inputs are:

$$
\begin{aligned}
N_{A, t}(x) & =\left(1-\gamma_{A, t}\right) p_{N, t}^{-\varepsilon_{A}} A_{t}(x) \\
Q_{A, t}(x) & =\gamma_{A, t} \nu_{A} p_{Q, t}^{-\mu_{A}} p_{X A, t}^{\mu_{A}-\varepsilon_{A}} A_{t}(x) \\
M_{A, t}(x) & =\gamma_{A, t}\left(1-\nu_{A}\right) p_{M A, t}^{-\mu_{A}} p_{X A, t}^{\mu_{A}-\varepsilon_{A}} A_{t}(x)
\end{aligned}
$$

where $p_{N}, p_{Q}$ and $p_{M A}$ are the relative prices of the inputs in terms of consumption baskets and $p_{X A}$ is the price of the composite basket of domestic and foreign tradables, or:

$$
p_{X A, t} \equiv\left[\nu_{A} p_{Q, t}^{1-\mu_{A}}+\left(1-\nu_{A}\right) p_{M A, t}^{1-\mu_{A}}\right]^{\frac{1}{1-\mu_{A}}}
$$

The technologies for the production of consumption and investment goods can be parametrized differently but their functional forms are the same, with self-explanatory changes in notation. For instance, a $\mathrm{rm} e \in[0, s]$ produces the investment good demands nontradable goods according to:

$$
N_{E, t}(e)=\left(1-\gamma_{E, t}\right)\left(p_{N, t} / p_{E, t}\right)^{-\varepsilon_{E}} E_{t}
$$

Note that $p_{M A}$ and $p_{M E}$ are sector-speci c as they re ect the different composition of imports described below - in the two sectors, while $p_{N}$ and $p_{Q}$ are identical across sectors.

\footnotetext{
${ }^{6} A$ is the numeraire of the economy and all national prices are expressed in terms of domestic consumption units, that is relative to the consumer price index (CPI).
} 


\section{B. Households}

\section{Consumer preferences}

In each country there is a continuum of households indexed by $j \in[0, s]$, the same index of labor inputs. Some households have access to capital markets, while others do not. The latter, indexed by $j \in\left[0, s\left(1-s_{L C}\right)\right]$, nance their consumption by relying exclusively on their income from labor and are a share $\left(1-s_{L C}\right)$ of total domestic households. The former are a share $s_{L C}$ of total domestic households and are indexed by $j \in\left(s\left(1-s_{L C}\right), s\right]$.

The speci cation of households' preferences adopts the Greenwood, Hercowitz and Huffman (1988) (GHH) utility function, adjusted for habit formation and preference shocks. Denoting with $\mathcal{W}_{t}(j)$ the lifetime expected utility of household $j$, we have:

$$
\mathcal{W}_{t}(j) \equiv \mathrm{E}_{t} \sum_{\tau=t}^{\infty} \beta^{\tau} g_{t, \tau}^{1-\sigma} u_{\tau}\left(C_{\tau}(j), \ell_{\tau}(j)\right)
$$

where the instantaneous felicity is a function of detrended consumption $C$ and labor effort $\ell$ :

$$
\begin{aligned}
& u_{t}\left(C_{t}(j), \ell_{t}(j)\right)=Z_{U}\left(1-\frac{b_{c}}{g_{t-1, t}}\right)\left(\frac{1-b_{\ell}}{1-\sigma}\right) \\
& *\left[\frac{C_{t}(j)-b_{c} C_{j, t-1} / g_{t-1, t}}{1-b_{c} / g_{t-1, t}}-\frac{Z_{V}}{1+\zeta}\left(\frac{\ell_{t}(j)-b_{\ell} \ell_{j, \tau-1}}{1-b_{\ell}}\right)^{1+\zeta}\right]^{1-\sigma}
\end{aligned}
$$

In the expressions above $\beta^{\tau}$ is the discount rate between time $t$ and time $\tau$, possibly different across countries. The term $g_{t, \tau}^{1-\sigma}$ in (A-34) implies that the disutility of labor effort increases with the common trend. As customary, this feature can be interpreted as technological progress associated with home production activities, here related to the global trend. The parameter $\sigma$ in (A-34) and (A-35) is the reciprocal of the elasticity of intertemporal substitution. The parameter $\zeta$ which affects the curvature of labor disutility is the reciprocal of the Frish elasticity.

There is habit persistence in consumption with coef cient $0<b_{c}<1$. The term $C_{j, t-1}$ in (A-35) is past per-capita consumption of household $j$ 's peers. Similarly, there is habit persistence in leisure with coef cient $0<b_{\ell}<1$. $^{7}$ The terms $Z_{U}$ and $Z_{V}$ are constants.

\footnotetext{
${ }^{7}$ The instantaneous felicity is normalized such that in a steady state $U, U_{C}$ and $U_{\ell}$ can all be written as constant $* f(C, \ell)$, where $f$ is some function of steady-state consumption and labor effort, independent of the habit persistence coef cients.
} 


\section{Budget constraint (Ricardian households)}

The individual ow budget constraint for Ricardian agent $j \in\left[0,\left(1-s_{L C}\right) s\right]$ is:

$$
\begin{aligned}
& B_{t}(j)+\varepsilon_{t} B_{t}^{*}(j) \leq\left(1+i_{t-1}\right) \frac{B_{t-1}(j)}{g_{t-1, t}}+\left(1+i_{t-1}^{*}\right)\left[1-\Gamma_{B, t-1}\right] \frac{\varepsilon_{t} B_{t-1}^{*}(j)}{g_{t-1, t}} \\
& +r_{t} K_{t}(j)+w_{t}(j) \ell_{t}(j)-C_{t}(j)-p_{E, t} I_{t}(j)+\Phi_{t}(j)-T T_{t}(j)
\end{aligned}
$$

where $T T_{t}<0$ is a positive transfer to households.

Households hold two real bonds: $B_{t}(j)$ represents (detrended) holdings of domestic bond by household $j$, expressed in terms of domestic consumption units, while $B_{t}^{*}(j)$ indicates (detrended) holdings of the international bond, expressed in terms of US consumption units, and $\varepsilon_{t}$ is the CPI-based, bilateral real exchange rate, expressed as the price of one unit of US consumption basket in terms of domestic consumption. ${ }^{8}$

The short-term real rates $i_{t}$ and $i_{t}^{*}$ are paid at the beginning of period $t+1$ and are known at time $t$. Only the US bond is traded internationally and is in zero net supply worldwide, while the domestic bond is issued by the local government. ${ }^{9}$ It follows that the net nancial wealth of Ricardian household $j$ at time $t$ is:

$$
F_{t}(j) \equiv\left(1+i_{t-1}^{*}\right)\left[1-\Gamma_{B, t-1}\right] \frac{\varepsilon_{t} B_{t-1}^{*}(j)}{g_{t-1, t}}
$$

A nancial friction $\Gamma_{B}$ is introduced to guarantee that international net asset positions follow a stationary process and that economies converge asymptotically to a well-de ned steady state. Agents who take a position in the international bond market must deal with nancial intermediaries who charge a transaction fee $\Gamma_{B}$ on sales/purchases of the international bond. ${ }^{10}$ This transaction cost is a function of the aggregate net foreign asset position of the whole economy. Speci cally, we adopt the following functional form:

$$
1-\Gamma_{B, t}=\left(1-\phi_{B 1} \frac{\exp \left(\phi_{B 2}\left[\varepsilon_{t} B_{t}^{*}-b_{F}^{*} G D P_{t}\right]\right)-1}{\exp \left(\phi_{B 2}\left[\varepsilon_{t} B_{t}^{*}-b_{F}^{*} G D P_{t}\right]\right)+1}\right)
$$

where $0 \leq \phi_{B 1} \leq 1, \phi_{B 2}>0$, and $\varepsilon_{t} B^{*} \equiv(1 / s) \varepsilon_{t} \int_{0}^{s\left(1-s_{L C}\right)} B^{*}(j) d j$ represents the per-capita net asset position of the country in consumption units. The term $b_{F}^{*}$ is the steady state net asset position of the country expressed as a ratio of $G D P .{ }^{11}$

\footnotetext{
${ }^{8}$ Note that $\varepsilon$ is shorthand for $\varepsilon^{H, U S}$, where $H$ denotes the country under consideration.

${ }^{9}$ If the country under consideration is the United States, $\varepsilon=1$ and $i=i^{*}$.

${ }^{10}$ In our model it is assumed that all intermediation rms are owned by the country's residents, and that their revenue is rebated to domestic households in a lump-sum form. A simple variant of the model in which intermediation rms are owned by foreign residents leaves the basic results virtually unchanged. There are no intermediation costs for US residents entering the international bond market, that is, there is no difference between onshore and offshore US interest rates. ${ }^{11}$ The concept of $G D P$ in our model will be discussed below with reference to (A-52).
} 
To understand the role played by $\Gamma_{B}$, suppose rst that $b_{F}^{*}=0$. In this case, when the net asset position of the country is equal to its steady state level of zero, it must be the case that $\Gamma_{B}=0$ and the return on the international bond is equal to $1+i^{*}$. If the country is a net creditor $\Gamma_{B}$ rises above zero, implying that domestic residents lose an increasing fraction of their international bond returns to nancial intermediaries. When holdings of the international bond go to in nity, the return on the international bond approaches $\left(1+i^{*}\right)\left(1-\phi_{B 1}\right)$. By the same token, if the country is a net debtor worldwide $\Gamma_{B}$ falls from zero to $-\phi_{B 1}$, implying that households pay an increasing intermediation premium on their international debt. When net borrowing goes to in nity, the cost of borrowing approaches $\left(1+i^{*}\right)\left(1+\phi_{B 1}\right)$. The parameter $\phi_{B 2}$ controls the atness of the $\Gamma_{B}$ function: if $\phi_{B 2}=0$ then $\Gamma_{B}=0$ regardless of the net asset position; if $\phi_{B 2}$ tends to in nity then $1-\Gamma_{B}=\left(1-\phi_{B 1}\right)$ for any arbitrarily small net lending position, and $1-\Gamma_{B}=\left(1+\phi_{B 1}\right)$ for any arbitrarily small net borrowing position. An appropriate parameterization allows the model to generate realistic dynamics for net asset positions and current account.

Households accumulate physical capital which they rent to domestic rms at rate $r$. The law of motion of capital is:

$$
K_{t+1}(j) g_{t, t+1}=(1-\delta) K_{t}(j)+\Gamma_{I, t} K_{t}(j) \quad 0<\delta \leq 1
$$

where $\delta$ is the country-speci c depreciation rate of capital. To simulate realistic investment ows, capital accumulation is subject to adjustment costs. Capital accumulation is denoted by $\Gamma_{I, t} K_{t}(j)$, where $\Gamma_{I}($.$) is an increasing, concave, and twice-continuously differentiable function of the$ investment/capital ratio $I_{t}(j) / K_{t}(j)$ with two properties entailing no adjustment costs in steady state: $\Gamma_{I}(\delta+g-1)=\delta+g-1$ and $\Gamma_{I}^{\prime}(\delta+g-1)=1$. The speci c functional form we adopt is quadratic and encompasses inertia in investment:

$$
\Gamma_{I, t}(j) \equiv \frac{I_{t}(j)}{K_{t}(j)}-\frac{\phi_{I 1}}{2}\left(\frac{I_{t}(j)}{K_{t}(j)}-(\delta+g-1)\right)^{2}
$$

where $\phi_{I 1} \geq 0$, and $g$ is the steady-state growth rate.

Each household $j$ is the monopolistic supplier of a speci c labor input and sets the nominal wage for its labor variety $j$ accounting for (A-9).

Ricardian households own all domestic rms and there is no international trade in claims on rms' pro ts. Finally, the variable $\Phi$ in the budget constraint includes all dividends accruing to shareholders, plus revenue from nancial intermediation which is assumed to be provided by domestic rms exclusively.

\section{Liquidity-constrained households}

A fraction of the population is composed by liquidity-constrained households, that do not borrow or save because of lack of access to nancial markets. Hence, they cannot smooth their consumption intertemporally. Each household is subject to the following budget constraint:

$$
C_{t}(j)=w_{t}(j) L_{t}(j)-T T_{t}(j)
$$


For simplicity we assume that the amount of hours worked, $L_{t}$, the real wage and the per capita amounts of net transfers from the scal authority are the same as the correspondent counterparts received by the forward-looking agents.

\section{Government}

Given that all prices and wages are fully exible, we impose that there is no role for monetary policy. For calibration purposes, we assume there is a scal authority in each country which consumes nal goods and collects lump-sum taxes following a simple feedback rule such that deviations of the government debt-to-GDP ratio from its target are temporary.

Speci cally, public spending falls exclusively on intermediate nontradable goods. The Home government budget constraint is:

$$
\frac{B_{G, t}}{R_{t}}-B_{G, t-1}=p_{N, t} G_{t}-T T_{X, t}
$$

$B_{G}$ is the negative of a riskless one-period real bond domestically sold (government debt). $T T_{X}$ are total lump-sum taxes (in consumption units) paid by the households. $R_{t}$ is the gross real interest rate. We assume that Ricardian and non-Ricardian agents are equally taxed. Taxes are set so as to stabilize the public debt:

$$
\left(\frac{T T_{X t}}{T T_{X}}\right)=\left(\frac{B_{G, t}}{B_{G}}\right)^{\phi_{B}}
$$

where $\phi_{B}>0$ and $T T_{X}$ and $B_{G}$ are the steady state values of tax and public debt.

\section{Market clearing and the current account}

The model is closed by imposing the following resource constraints and market clearing conditions, adopting explicit country indexes.

For every country $H$, the domestic resource constraints for capital and labor are, respectively:

$$
\int_{0}^{s^{H}\left(1-s_{L C}^{H}\right)} K_{t}^{H}\left(j^{H}\right) d j^{H} \geq \int_{0}^{s^{H}} K_{t}^{H}\left(n^{H}\right) d n^{H}+\int_{0}^{s^{H}} K_{t}^{H}\left(h^{H}\right) d h^{H}
$$

and:

$$
\ell_{t}^{H}\left(j^{H}\right) \geq \int_{0}^{s^{H}} \ell_{t}^{H}\left(n^{H}, j^{H}\right) d n^{H}+\int_{0}^{s^{H}} \ell_{t}^{H}\left(h^{H}, j^{H}\right) d h^{H}
$$

The resource constraint for the nontradable good $n^{H}$ is:

$$
N_{t}^{H}\left(n^{H}\right) \geq \int_{0}^{s^{H}} N_{A, t}^{H}\left(n^{H}, x^{H}\right) d x^{H}+\int_{0}^{s^{H}} N_{E, t}^{H}\left(n^{H}, e^{H}\right) d e^{H}+\eta(n) \int_{0}^{s^{H}} T_{t}\left(h^{H}\right) d h^{H}+G_{t}
$$


while the tradable $h^{H}$ can be used by domestic rms or imported by foreign rms:

$$
\begin{aligned}
& T_{t}\left(h^{H}\right) \geq \int_{0}^{s^{H}} Q_{A, t}\left(h^{H}, x^{H}\right) d x^{H}+\int_{0}^{s^{H}} Q_{E, t}\left(h^{H}, e^{H}\right) d e^{H} \\
& +\sum_{C O \neq H}\left(\int_{0}^{s^{C O}} M_{A, t}^{C O, H}\left(h^{H}, x^{C O}\right) d x^{C O}+\int_{0}^{s^{C O}} M_{E, t}^{C O, H}\left(h^{H}, e^{C O}\right) d e^{C O}\right)
\end{aligned}
$$

The nal good $A$ can be used for private consumption (by both liquidity-constrained and forward-looking households):

$$
\int_{0}^{s^{H}} A_{t}^{H}\left(x^{H}\right) d x^{H} \geq \int_{0}^{s^{H}\left(1-s_{L C}^{H}\right)} C^{H}\left(j^{H}\right) d j^{H}+\int_{s^{H}\left(1-s_{L C}^{H}\right)}^{s^{H}} C^{H}\left(j^{H}\right) d j^{H}
$$

and similarly for the investment good $E$ :

$$
\int_{0}^{s^{H}} E_{t}^{H}\left(e^{H}\right) d e^{H} \geq \int_{0}^{\left(1-s_{L C}^{H}\right) s^{H}} I_{t}^{H}\left(j^{H}\right) d j^{H}
$$

Market clearing in the asset market requires:

$$
\int_{0}^{s^{H}\left(1-s_{L C}^{H}\right)} B_{t}^{H}\left(j^{H}\right) d j^{H}=s^{H} B_{t}^{H}
$$

for the ve government bond markets, and:

$$
\sum_{C O} \int_{0}^{s^{C O}\left(1-s_{L C}^{C O}\right)} B_{t}^{* C O}\left(j^{C O}\right) d j j^{C O}=0
$$

\section{E. Measuring output and current account}

The current account balance of country $H$ can be written as:

$$
C U R B A L_{t}^{H}=\varepsilon_{t}^{H, U S}\left(B_{t}^{* H}-\frac{B_{t-1}^{* H}}{g_{t-1, t}}\right)=\frac{i_{t-1}^{*} \varepsilon_{t}^{H, U S} B_{t-1}^{* H}}{g_{t-1, t}}+T B A L_{t}^{H}
$$

The left hand side of (A-48) represents algebraically country $H$ 's current account, the rst term on the right hand side indicates net factor payments from the rest of the world to country $H$ and $T B A L$ is the trade balance. The latter can be expressed in symbols as:

$$
T B A L_{t}^{H}=E X_{t}^{H}-I M_{t}^{H}
$$

where total exports $E X$ are:

$$
E X_{t}^{H}=p_{T, t}^{H} T_{t}^{H}-p_{Q, t}^{H}\left(Q_{A, t}^{H}+Q_{E, t}^{H}\right)
$$


and total imports $I M$ are:

$$
I M_{t}^{H}=p_{M A, t} M_{A, t}^{H}+p_{M E, t} M_{E, t}^{H}=\sum_{C O \neq H} p_{M, t}^{H, C O}\left(M_{A, t}^{H, C O}+M_{E, t}^{H, C O}\right)
$$

Finally, we de ne the model-based Gross Domestic Product (in consumption units) as:

$$
G D P_{t}^{H}=A_{t}^{H}+p_{E, t}^{H} E_{t}^{H}+E X_{t}^{H}-I M_{t}^{H}=p_{N, t}^{H} N_{t}^{H}+p_{T, t}^{H} T_{t}^{H}
$$

so that:

$$
C U R B A L_{t}^{H}=T B A L_{t}^{H}+\frac{i_{t-1}^{*} \varepsilon_{t}^{H, U S} B_{t-1}^{* H}}{g_{t-1, t}}=G D P_{t}^{H}-\left(C_{t}^{H}+p_{E, t}^{H} I_{t}^{H}\right)+\frac{i_{t-1}^{*} \varepsilon_{t}^{H, U S} B_{t-1}^{* H}}{g_{t-1, t}}
$$

Note that, while theoretically consistent with the model, this measure of output is not consistent with standard, xed-weight, constant-dollar measures of real GDP constructed by national accounts. The problem is particularly severe for relatively open economies facing large swings in real exchange rates and relative prices. In the simulations, we therefore adopt 'national accounts' concepts for $G D P, T B A L$ and their components, evaluating constant-dollar expenditures at any time $t$ by using xed steady-state prices instead of the corresponding relative prices at time $t$.

\section{F. The equilibrium}

We nd a symmetric equilibrium of the model. In each country there are two representative agents (Ricardian and non-Ricardian) and four representative rms (belonging to the intermediate tradable sector, the intermediate nontradable sector, the consumption production sector and the investment production sector). The equilibrium is a sequence of allocations and prices such that, given initial and transversality conditions and the sequence of exogenous shocks, each private agent and rm satisfy the correspondent rst order conditions such that market clearing conditions hold.

\section{CALIBRATiON}

To calibrate the model we rely on previous GEM work at the IMF (e.g., Hunt and Rebucci (2005), Batini, N'Diaye, Rebucci (2005), Faruquee et al. (2007)) and on the real business cycle and trade literature. Table A1 provides a data benchmark for the steady state of the model. Tables A2 through A5 document the parameterization adopted.

Table A2 reports the parameter governing the optimization problem of households and rms. The share of non Ricardian households is 10 percent, in all ve regional blocs. Although households differ with respect to their access to nancing, the preferences of the liquidity-constrained and forward-looking households are identical. We set identical discount factors, at 0.997, which implies a steady state quarterly real interest rate of 0.53 percent, and unitary elasticities of intertemporal substitution in consumption (i.e., logarithmic period utility). For labor, we assume a common value for the Frish elasticity of 0.67 . The elasticity of substitution between labor and 
capital is set at 0.75 in both the tradable and non-tradable sectors. This is slightly lower than the conventional (Cobb-Douglas) unitary assumption to help reduce the sensitivity of capital to changes in its relative price. The bias towards the use of capital, sector-specific but common across countries, yields a slightly higher investment share of GDP for emerging Asia (close to 18 percent) relative to the other blocks, whose investment shares are very similar (between 15 and 16 percent). In all regions, the non-tradable sector (e.g., services) is assumed to be less capital-intensive than the tradable sector (e.g., manufacturing). The depreciation rate is assumed to be 2 percent per quarter across all regions (8 percent per year). Following the trade literature, as well as Engel and Rogers (2006), we set the elasticity of substitution between imported goods and that between (domestic and imported) tradeable to a relatively high level, equal to 4, thus typically higher than in the GEM. The substitution between tradable and non-tradable is set to a more conventional level of 0.5 , consistent with the GEM.

The only real rigidities that we keep are described in Table A3. The distribution cost parameter is set at 0.3 , a value very close to that used in the GEM. Following the RBC literature, the capital adjustment cost parameter is set very low, at 0.01 , and habit persistence on consumption and labor, as well as adjustment costs on investment, are set to 0 (not reported in Table A3).

There are separate mark-ups on tradable and non-tradable goods since firms have pricing power under monopolistic competition (Table A4). We use estimates for the price mark-ups from Martins, Scarpetta, and Pilat (1996) and take the simple average of their sector-specific values for the United States, Japan, the euro area, and the rest of the world. This yields average mark-ups of 18 and 35 percent for the traded and non traded sectors, respectively. In the labor market, we assume agents have the same pricing power, yielding a 20 percent wage mark-up in all regions.

The calibration of each international linkages is reported in Table A5. The regional composition of imports in Table A5, as well as the weight coefficients in the demand function for imports in Table A2, are consistent with the matrix of trade shares (at end 2002) used to calibrate the IMF GEM. The elasticity of substitution among baskets of imports from different countries is slightly higher than the elasticity between home and foreign tradable goods, at 5 . The maximum and the steepness of the financial intermediation cost on net foreign asset holdings are set as in the GEM at 0.05 and 0.1 , respectively.

The common gross rate of growth, $g_{t \tau}$, is set to one. This corresponds to assuming that the model is stationary and there is no underlying trend growth.

\section{TRANSMISSION}

To better illustrate the transmission mechanism implied by the model, we report the impulse response to unitary TFP shocks in the United States. To do so, we assume that technology follow AR(1) processes with autoregressive coefficient equal to 0.99 , with no correlation across sectors or countries, in both the tradable and non-tradable sector, and solve the model for its rational expectation equilibrium (always in DYNARE). 
Figure A1 and A2 report the impulse responses to these TFP shocks in the tradable and non-tradable sector, respectively. ${ }^{12}$ A temporary but persistent TFP increase in the U.S. tradable sector leads to a persistent trade balance improvement and an effective exchange rate appreciation with our calibration (Figure A1). Key to understand the trade balance response are the high elasticity of substitution between domestically and foreign produced tradable goods, the low elasticity between tradable and nontradable goods (implying that domestic and imported tradable are substitute while domestic tradables and nontradables are complement), and the high shares of domestic tradable goods and non tradable goods in U.S. investment and consumption, respectively.

The higher TFP level leads to lower marginal costs and relative prices in the U.S. tradable sector, and hence to a terms of trade deterioration for the United States. As the elasticity of substitution between home and foreign tradables is above one, output increases more than the price falls, with a positive income and wealth effect. Firms in the tradable sector take advantage of higher productivity and lower costs and expand output, also increasing factor demand and remunerations, with a positive effect on income and wealth. U.S. investment is intensive in domestic tradables, so higher demand for capital can be met in part with higher U.S. production of tradables. As the relative price of tradable goods has fallen, world aggregate demand for U.S. tradable goods increases. Tradable and non-tradable goods are complements, therefore consumption of non-tradable goods also increases on impact. After the initial increase, the relative price of non tradable goods gradually reverts back toward its steady state value, and consumption of non tradable goods increases further, pulling along overall consumption, given this is intensive in non-tradables. As a result, aggregate consumption has an hump-shaped response to the shock with our calibration, and the trade balance improves, despite the increases in aggregate investment.

The relatively high weight of non-tradables in the consumption baskets and our calibration of the trade elasticities generate a persistent Harrod-Balassa-Samuelson (HBS) effect, with the increase in the relative price of non tradable goods dominating the fall in the relative price of the tradable goods and the associated terms of trade deterioration. As a result the real exchange rate appreciates persistently in response to this shock.

This transmission mechanism is fairly robust. With lower elasticities of substitution between home and foreign tradable goods (i.e., 2, about the same as those used by Faruque et al (2007)), the terms of trade deterioraton is lower and much more persistent, the shift of world demand toward U.S. tradable goods is smaller, and the consumption increase is more frontloaded (as the initial fall in the relative price of tradables is lower and more persistent). This results in a larger deterioration of the trade balance. With even higher elasticity of substitution (i.e., 6, as in Engel and Rogers (2006)) we find a larger surplus. Neither of these changes affects the the sign of the exchange rate responses though.

\footnotetext{
${ }^{12}$ The responses are absolute deviations from steady state levels. Note also that the terms of trade and the relative price of nontradables are defined as import over export prices (i.e. an increase corresponds to a terms of trade deterioration), and as nontradable prices over domestic consumer prices, respectively. As a result, an increase in the real effective exchange rate is a depreciation.
} 
The same intuition explains why, in contrast, a productivity acceleration in the U.S. non-tradable sector, leads to a persistent deterioration of the U.S. trade balance and an effective exchange rate depreciation (Figure A2). Specifically, in response to a TFP shock in the non-tradable sector, marginal costs and relative prices fall in this sector. U.S. demand of non-tradables increases. However, the complementarity between tradable and non-tradable and the large size of the nontradable sector imply that consumption and the relative price of tradable goods also increase, with an improvement in the terms of trade. Foreign demand for U.S. tradable goods decreases, and therefore the U.S. trade balance deteriorates. Firms in both sectors expand output, and investment (intensive in tradable goods) increases sharply, lifting the U.S. import demand. The U.S. real exchange rate depreciates, despite a terms of trade improvement, because the relative price of nontradables appreciates, given that non tradable goods have a relatively high weight in the consumer price index. 
Table A1: Steady-state National Accounts (In percent of GDP)

\begin{tabular}{llllll}
\hline & US & JA & AS & EA & ROW \\
\hline Private Consumption & & & & & \\
Forward-looking consumers & 68.96 & 59.64 & 69.33 & 58.99 & 67.83 \\
Liquidity-constrained consumers & 62.64 & 52.56 & 54.71 & 54.73 & 62.00 \\
Private Investment & 6.31 & 7.08 & 14.60 & 4.25 & 5.83 \\
Public Expenditure & 15.94 & 21.08 & 19.34 & 15.32 & 15.73 \\
Trade balance & 14.51 & 19.78 & 12.1 & 25.5 & 16.8 \\
Imports & 0.60 & -0.41 & -0.64 & 0.18 & -0.37 \\
Consumption Goods & 11.46 & 11.49 & 26.73 & 17.41 & 22.98 \\
Investment Goods & 7.33 & 8.06 & 11.32 & 15.01 & 12.13 \\
\hline Government Debt & 4.13 & 3.43 & 15.40 & 2.40 & 10.85 \\
Net Foreign Assets & 61.5 & 80.0 & 55.0 & 60.0 & 60.0 \\
Share of World GDP (percent) & -51.08 & 55.03 & 49.02 & -11.3 & 26.4 \\
\hline Source: Batini, NDiaye, Reburi & 30.05 & 11.48 & 9.83 & 22.80 & 25.84 \\
\hline
\end{tabular}

Source: Batini, N’Diaye, Rebucci (2005). 
Table A2: Households and Firms Behavior

\begin{tabular}{llllll}
\hline & US & JA & AS & EA & ROW \\
\hline & & & & & \\
\hline Rate of time preference & .997 & .997 & .997 & .997 & .997 \\
Depreciation rate & 0.02 & 0.02 & 0.02 & 0.02 & 0.02 \\
Intertemporal elasticity of substitution & 1.00 & 1.00 & 1.00 & 1.00 & 1.00 \\
Inverse of the Frisch elasticity of labor & 1.50 & 1.50 & 1.50 & 1.50 & 1.50 \\
\hline Share of liquidity-constrained consumers & 0.10 & 0.10 & 0.10 & 0.10 & 0.10 \\
\hline Tradable Intermediate Goods & & & & & \\
\hline Substitution between factors of production & 0.75 & 0.75 & 0.75 & 0.75 & 0.75 \\
Bias towards capital & 0.60 & .60 & 0.60 & 0.60 & 0.60 \\
\hline Nontradable Intermediate Goods & & & & & \\
\hline Substitution between factors of production & 0.75 & 0.75 & 0.75 & 0.75 & 0.75 \\
Bias towards capital & 0.50 & .50 & 0.50 & 0.50 & 0.50 \\
\hline Final consumption goods & & & & & \\
\hline Substitution between domestic and imported goods & 4 & 4 & 4 & 4 & 4 \\
Bias towards domestic goods & 0.87 & 0.49 & 0.15 & 0.04 & 0.20 \\
Substitution between tradables and nontradables & 0.50 & 0.50 & 0.50 & 0.50 & 0.50 \\
Bias towards tradable goods & 0.35 & 0.36 & 0.37 & 0.36 & 0.30 \\
\hline Final investment goods & & & & & \\
\hline Substitution between domestic and imported goods & 4 & 4 & 4 & 4 & 4 \\
Bias towards domestic goods & 0.87 & 0.63 & 0.06 & 0.92 & 0.14 \\
Substitution between tradables and nontradables & 0.50 & 0.50 & 0.50 & 0.50 & 0.50 \\
Bias towards tradable goods & 0.75 & 0.77 & 0.82 & 0.75 & 0.73 \\
\hline
\end{tabular}

Table A3: Real rigidities

\begin{tabular}{llllll}
\hline & US & JA & AS & EA & ROW \\
\hline Capital accumulation & 0.01 & 0.01 & 0.01 & 0.01 & 0.01 \\
\hline Distribution costs & 0.30 & 0.30 & 0.30 & 0.30 & 0.30 \\
\hline
\end{tabular}

Table A4: Price and Wage Markups

\begin{tabular}{lccccc}
\hline & US & JA & AS & EA & ROW \\
\hline Tradables Price Markups & & & & & \\
& 1.18 & 1.18 & 1.18 & 1.18 & 1.18 \\
Nontradables Price Markups & & & & & \\
Wage Markup & 1.35 & 1.35 & 1.35 & 1.35 & 1.35 \\
& 1.20 & 1.20 & 1.20 & 1.20 & 1.20 \\
\hline
\end{tabular}


Table A5: International Linkages

\begin{tabular}{llllll}
\hline & US & JA & AS & EA & ROW \\
\hline Substitution between consumption imports & 5 & 5 & 5 & 5 & 5 \\
\hline Bias towards imported consumption goods from & & & & & \\
\hline US & $\ldots$ & 0.45 & 0.23 & 0.04 & 0.39 \\
JA & 0.06 & $\ldots$ & 0.12 & 0.03 & 0.01 \\
AS & 0.17 & 0.38 & $\ldots$ & 0.14 & 0.02 \\
EA & 0.16 & 0.10 & 0.25 & $\ldots$ & 0.58 \\
ROW & 0.61 & 0.07 & 0.40 & 0.79 & $\ldots$ \\
\hline Substitution between investment imports from & 5 & 5 & 5 & 5 & 5 \\
\hline Bias towards imported investment goods from & & & & & \\
\hline US & $\ldots$ & 0.53 & 0.26 & 0.26 & 0.37 \\
JA & 0.06 & $\ldots$ & 0.13 & 0.05 & 0.04 \\
AS & 0.28 & 0.25 & $\ldots$ & 0.14 & 0.16 \\
EA & 0.16 & 0.13 & 0.12 & $\ldots$ & 0.43 \\
ROW & 0.50 & 0.09 & 0.49 & 0.55 & $\ldots$ \\
\hline Net Foreign Liabilities & & & & & \\
\hline Maximum of nancial intermediation cost function & 0.05 & 0.05 & 0.05 & 0.05 & 0.05 \\
Steepness of nancial intermediation cost function & 0.1 & 0.1 & 0.1 & 0.1 & 0.1 \\
& & & & &
\end{tabular}


Figure A1. US Tradable TFP Shock
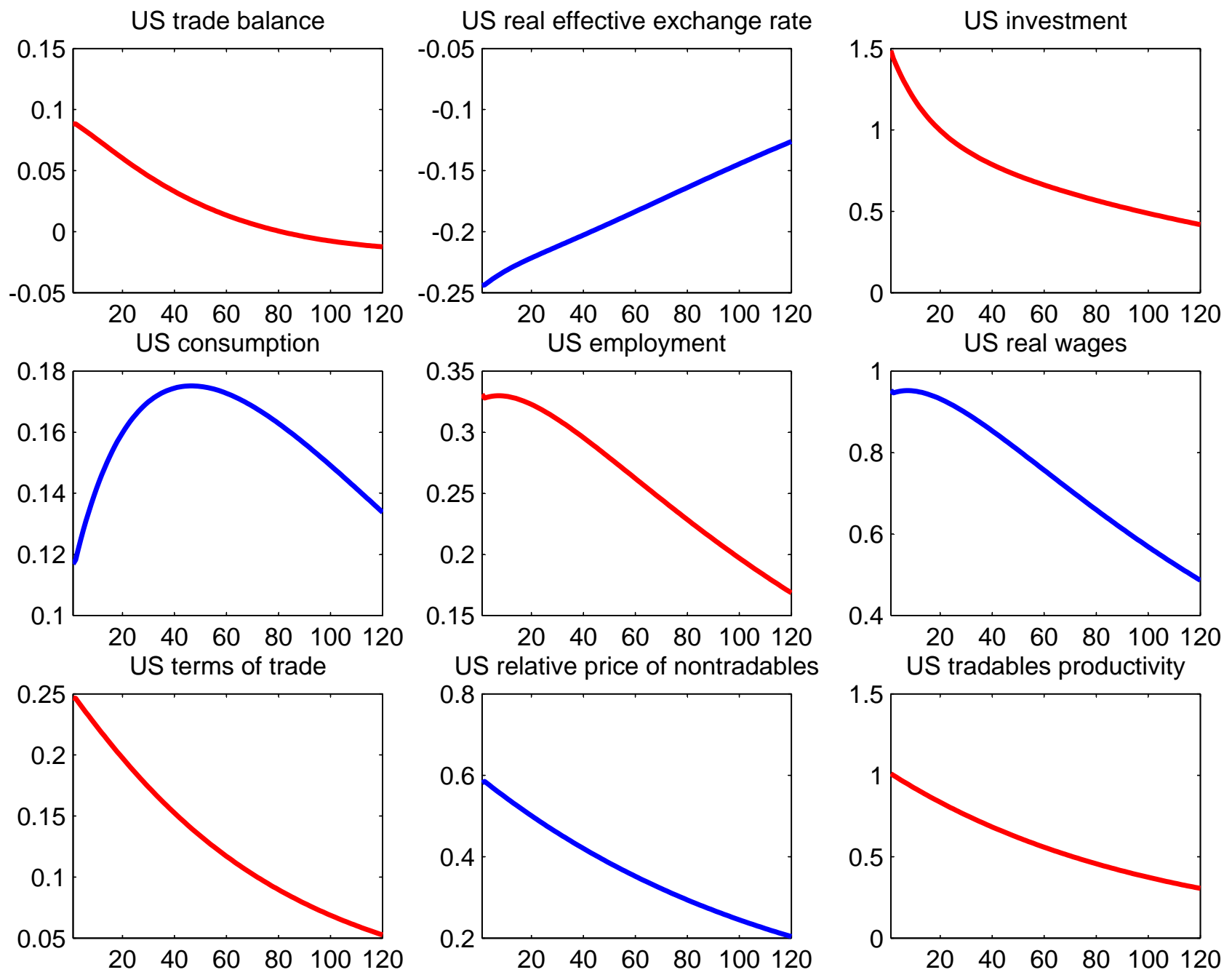
Figure A2. US Non-Tradable TFP Shock
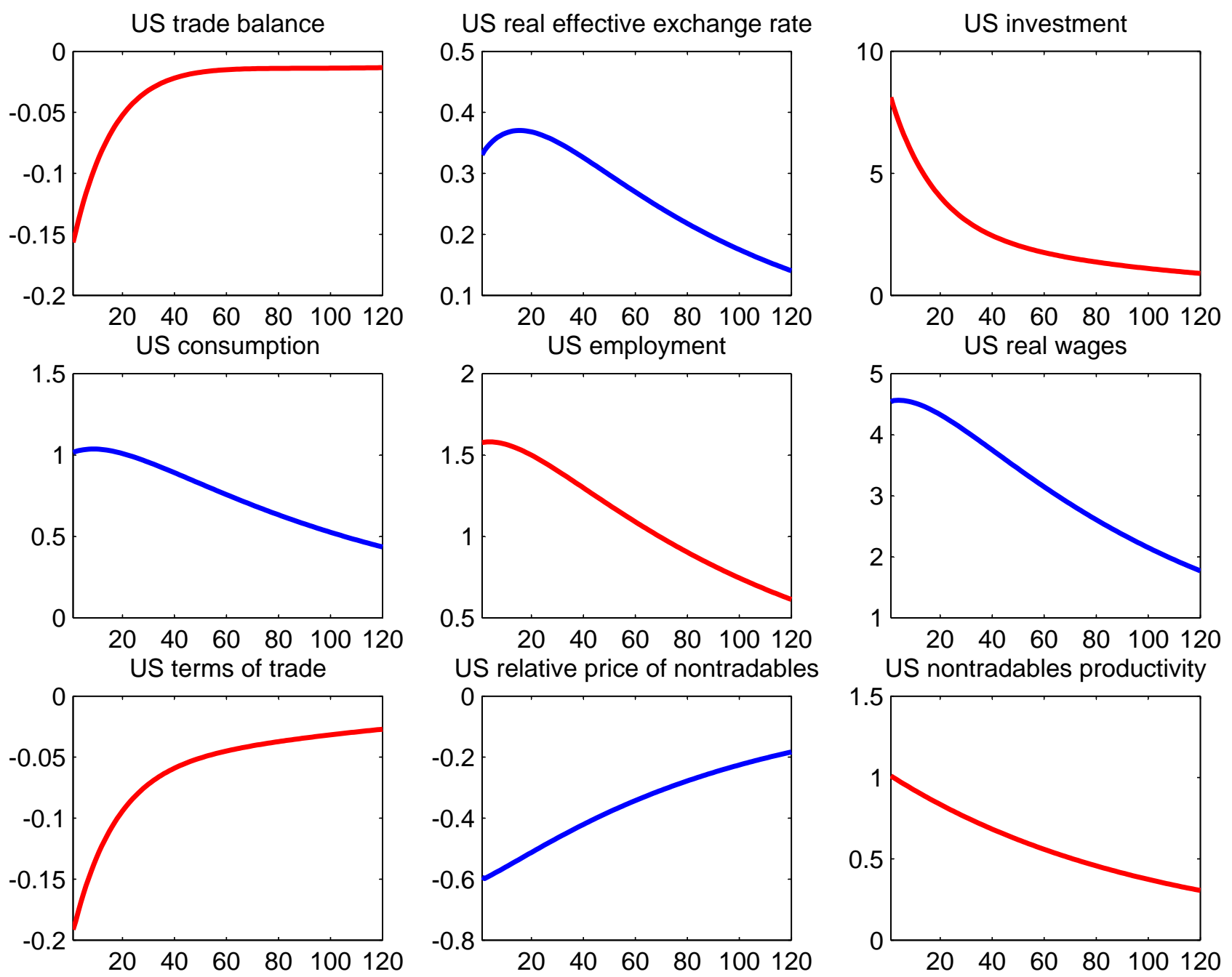


\section{REFERENCES}

Batini, N, N'Diaye, P and A Rebucci, 2005. “The Domestic and Global Impact of Japan's Policies for Growth”, Federal Reserve Bank of San Francisco Proceedings series (Also vailable as IMF Working Papers No. 05/209, International Monetary Fund).

Basu Susanto and John Fernald (2006), "Information and Communications Thechnology as a General-Purpose Technology: Evidence from U.S. Industry Data” Federal Reserve Bank of San Francisco Working Paper No. 2006-29.

Bems, R, Dedola, L and F Smets, 2007.’US Imbalances: the role of technology and policy”. European Central Bank WP No. 719.

Blanchard, O, 2006. "Current Account Deficits in Rich Countries”. Paper presented at the IMF Seventh Jacques Polak Annual Research Conference on "Capital Flows”, November 910, 2006, Washington D.C.

Blanchard, O, Giavazzi, F, and Sa, F, 2005. "The U.S. Current Account and the Dollar”. NBER Working Paper No. 11137 (forthcoming in the Brookings Papers on Economic Activity).

Caballero, R J, Fahri, E, and P-O Gourinchas, 2006. “An Equilibrium Model of 'Global Imbalances' and Low Interest Rates”. NBER Working Paper No. 11996.

Corsetti, G, Dedola, L and S Leduc, 2007. "Productivity, External Balance and Exchange Rates: Evidence on the Transmission Mechanism Among G7 Countries", forthcoming in Lucrezia Reichlin and Kenneth West (eds.) NBER International Seminar on Macroeconomics 2006. Revised version November 2006.

Cova, Pietro and Massimiliano, Pisani, 2007, “A General Equilibrium Model of the World Economy”, unpublished manuscript, Banca d'Italia.

Cova, Pietro and Massimiliano Pisani (2009) "Global Imbalances: The Role of Emerging Asia”, forthcoming in the Review of International Economics.

Edwards, S, 2007. “On Current Account Surpluses and the Correction of Global Imbalances”. NBER Working Papers No. 12904.

Faruqee, H, Laxton, D, Muir, D and P Pesenti, 2007. "Smooth Landing or Crash? Model-Based Scenarios of Global Current Account Rebalancing”. NBER Working Papers No. 11583.

Fogli, A and F Perri, 2006. “The 'Great Moderation’ and the US External Imbalance”. NBER Working Paper No. W12708.

Gordon R. (2004), "Five Puzzles in the Behavior of Productivity, Investment, and Innovation," NBER Working Paper No. 10662, August 2004. 
Hunt, B and A, Rebucci, 2005. "The US Dollar and the Trade Deficit: What Accounts for the Late 1990s?”. International Finance, Blackwell Publishing, vol. 8(3), pages 399-434, December.

Jorgenson D. and with K. Motohashi, “Information Technology and the Japanese Economy,” Journal of the Japanese and International Economies, Vol. 19, No. 4, December 2005, pp. 460-481.

Jaumotte, F and N, Spatafora, 2006. “Asia Rising: Patterns of Economic Development and Growth”. Chapter III, World Economic Outlook, September 2006, International Monetary Fund.

Jorgennson D., "Information Technology and the G7 Economies (updated manuscript and tables)," World Economics, Vol. 4, No. 4, October-December, 2003, pp. 139-169; updated and reprinted in Revista di Politica Economica, Vol. 95, Nos. 1-2, January-February 2005, pp. 25-56.

Julliard M. (1996), “Dynare: A program for the resolution and simulation of dynamic models with forward variables through the use of a relaxation algorithm,” CEPREMAP, Couverture Orange, 9602).

Martins, J O, Scarpetta, S and D Pilat, 1996. "Mark-Up Ratios in Manufacturing Industries: Estimates for 14 OECD Countries”. OECD Economics Department Working Papers No. 162.

Mendoza, Enrique G., and Linda Tesar (1998), "The International Ramifications of Tax Reforms; Supply-Side Economics in a Global Economy", American Economic Review, 1998, v. 88, p. 226-245.

Mendoza, E G, Rios-Rull, J-V and V Quadrini, 2007. “Financial Integration, Financial Deepness and Global Imbalances”. NBER Working Papers 12909.

Mussa, M, 2004.”Exchange Rate Adjustments Needed to Reduce Global Payments Imbalances”, in C. Fred Bergsten and John Williamson (eds.), Dollar Adjustment: How Far? Against What? Washington, D.C.: Institute for International Economics, pp. 113-138.

Oliner S. D., D. E. Sichel and K. J. Stiroh, “Explaining a Productive Decade,” Brookings Papers on Economic Activity, Spring 2007.

Obstfeld, M and K Rogoff, 2005. "Global Current Account Imbalances and Exchange Rate Adjustments" (forthcoming in the Brookings Papers on Economic Activity).

Roubini, N and B Setser, 2004. "The U.S. as a Net Debtor: The Sustainability of the U.S. External Imbalances”, unpublished manuscript, Stern School of Business, New York University.

Yoshitomi, M, 2006. “Global Imbalances and East Asian Monetary Cooperation” in Duck-Koo Chung and Barry Eichengreen (eds.), Toward an East Asian Exchange Rate Regime (forthcoming). 